IZA DP No. 9591

An Unfulfilled Promise?

Higher Education Quality and Professional

Underemployment in Peru

Gustavo Yamada

Pablo Lavado

Joan J. Martínez

December 2015 


\title{
An Unfulfilled Promise? Higher Education Quality and Professional Underemployment in Peru
}

\author{
Gustavo Yamada \\ University of the Pacific, Lima \\ and IZA \\ Pablo Lavado \\ University of the Pacific, Lima \\ Joan J. Martínez \\ University of the Pacific, Lima
}

\section{Discussion Paper No. 9591 December 2015}

\author{
IZA \\ P.O. Box 7240 \\ 53072 Bonn \\ Germany \\ Phone: +49-228-3894-0 \\ Fax: +49-228-3894-180 \\ E-mail: iza@iza.org
}

Any opinions expressed here are those of the author(s) and not those of IZA. Research published in this series may include views on policy, but the institute itself takes no institutional policy positions. The IZA research network is committed to the IZA Guiding Principles of Research Integrity.

The Institute for the Study of Labor (IZA) in Bonn is a local and virtual international research center and a place of communication between science, politics and business. IZA is an independent nonprofit organization supported by Deutsche Post Foundation. The center is associated with the University of Bonn and offers a stimulating research environment through its international network, workshops and conferences, data service, project support, research visits and doctoral program. IZA engages in (i) original and internationally competitive research in all fields of labor economics, (ii) development of policy concepts, and (iii) dissemination of research results and concepts to the interested public.

IZA Discussion Papers often represent preliminary work and are circulated to encourage discussion. Citation of such a paper should account for its provisional character. A revised version may be available directly from the author. 


\section{ABSTRACT \\ An Unfulfilled Promise? Higher Education Quality and Professional Underemployment in Peru*}

Despite the high growth of the Peruvian economy during the last decade, college graduates are facing increasing difficulties to find occupations that match their higher educational background, skills and educational investments. This scenario is embodied in the "professional underemployment" condition by which 4 out of 10 college graduates, by 2012 , are overeducated, occupying non-professional and sub-paid positions. We propose that the deterioration in higher education quality has been a trigger for the increase in underemployment of university graduates, as an alternative to the literature that analyzes its causes related to labor demand. The main objective is to explore and quantify the extent to which higher education quality contributes to professional underemployment in Peru. Using data from the National Household Survey for the period 2004-2012 and the National University Census for the years 1996 and 2010, we propose a discrete choice model that measures the impact of college quality on the individual condition of underemployment in the long run. The source of variability for identifying this effect is the institutional and legal process of deregulation of universities initiated in the nineties. Our results indicate that the probability of being underemployed among graduates who attended "lower quality" universities increased from 0.19 to 0.30 beginning the college market deregulation. These estimation consider a twofold effect of deregulation, over the quality of university to which university applicants are prone to attend and in the probability of acquiring university education among individuals with lower academic skills.

JEL Classification: $\quad \mathrm{C} 21, \mathrm{~J} 23, \mathrm{~J} 24, \mathrm{~J} 44, \mathrm{~J} 64$

Keywords: discrete choice models, employment determination, occupational choice, human capital, professional labor markets and occupation, unemployment

Corresponding author:

Gustavo Yamada

Department of Economics

Universidad del Pacífico

Av. Salaverry 2020

Lima 11

Peru

E-mail: yamada_ga@up.edu.pe

\footnotetext{
* We thank the participants of the presentation of this research at the Research Centre of the University of the Pacific, held on May 30,2014, for their valuable comments to previous versions of this document. Subsistent mistakes are the responsibility of the authors.
} 


\section{Introduction}

The recent increase in rates of underemployment among university graduates worldwide has led to doubts about the actual returns of college education ${ }^{1}$. An example is underemployment in Peru, which has shown a persistent upward trend equivalent to eleven percentage points over the analysis period 2004-2012, despite the context of economic expansion, with a GDP growth rate of around 5.6\% over 10 years (2000-2012). While the economy has had an overall positive behavior, difficulties faced by college graduates to obtain jobs that enable them to exercise their professional training or to live up to expectations of a remuneration professional have become more common. Representative cases of underemployment in the country include that of experienced professionals whose prospects of «white collar jobs» are exchanged for taxi cabs. Likewise, recently graduated university students can be hardly satisfied with dress uniforms of international fast food franchises for a living.

Numerous studies have attributed the cause of professional underemployment to various types of «mismatch» between supply and demand in the labor market (e.g. due to skills or geographic availability) which prevent graduates to get jobs (see Alba-Ramirez 1993 Manacorda et al., 1998, Allen \& Van der Valdes 2001, Handel 2003, Shimer 2005, McGuinness 2006). The literature has documented the role of demand factors (e.g. hiring rates) and dynamics in labor markets, an approach justified in the analysis of underemployment in the U.S. and several European countries that have experienced declines in productive sectors (see Liagouras 2003, Di Pietro et al. 2006, Korpi et al. 2006, CEDEFOP 2010, Sahin et al., 2011). However, based on the work of Black \& Smith (2004) and Long (2008), our study takes one step back with respect to the labor market as we analyze a plausible cause of underemployment in a previous instance: the higher education market. In this line, an extensive literature suggests that the components of university quality, such as prestige in the labor market, the adequacy of college training and the set of cognitive and non-cognitive skills developed during the university period, are related to employment conditions reached as graduates (Cohodes \& Goodman 2012, Dale \& Krueger 2011, Hoekstra 2009, Black \& Smith 2006, Belzil \& Hansen 2002, Brewer \& Ehrenberg 1996).

Our main objective is to quantify the extent to which the quality of higher education institutions contributes to professional underemployed. With this purpose, this paper analyzes the case of Peru, a country whose system of higher education currently lacks of university rankings, wage monitoring systems or quality measures issued by the government agencies or an accredited official source ${ }^{2}$. Thus, we place in a context of incomplete

\footnotetext{
${ }^{1}$ In U.S. the underemployment rate varies between $9 \%$ and $8 \%$ of the population of working age during the period extending from 2010 to 2013; while the professional underemployment is between 7\% and 6.8\% for the same period (Federal Bank of New York 2013). Meanwhile, professional unemployment was around 33\% for the 2008-2010 period post financial crisis.

${ }^{2}$ There is limited information on the returns to college education due to the lack of integrated information systems in Peru, unlike the Chilean case (see web site of the social program "My Future»). Also, there are unofficial rankings such as the one annually published by the Magazine American Economy (2010, 2012, 2013), which to its latest edition does not cover all the country's universities.
} 
information about college wage returns specific to each type of institution depending on its quality. Specifically, we examine the effect of an exogenous increase in the number of universities on the professional underemployment rate, for which we will use as an identification strategy the exogenous decline in university quality as consequence of the creation of the National Council for the Authorization for Operation of Universities (CONAFU) in 1995 - see Section 3.1 for further details. We propose that the increase in underemployment in the country was triggered as a result of two components of liberalization in the higher education market: the rise of lower quality universities and higher education students with relatively lower academic skills who, therefore, are beforehand more likely (or independent of the upper education received) to be underemployed. In view of this, the aim of this study is to estimate an overall effect of the decline in university quality and distinguish the individual effects of these two components, for which the research is conducted in two stages.

First, we propose a comprehensive definition of professional underemployment based on information from the National Household Survey (ENAHO) of Peru for the period extending from 2004 to 2012. The estimated underemployment rate is representative at regional and national levels. Underemployment is the central variable of this study as it summarizes the long-term effects of educational quality. Our definition incorporates features often addressed in empirical studies of this phenomenon, such as over-education (see, e.g. McGuinness \& Doyle 2004, Groot 2000, McGuinness 2004), employment in non-professional occupations (see Leuven \& Oosterbeek 2011, Sahin et al., 2011) and the condition of under-paid (see Jones-Johnson et al. 1992, Maynard 2006). Stylized facts that describe the recent evolution of professional underemployment are presented through the paper.

Secondly, we propose an empirical strategy to measure how much more likely to be underemployed is a professional who has attended a «lower quality» college compared with one that has attended «higher quality» institutions (see definition in section 6). For our estimations, we use the exogenous variation in the supply of universities that resulted from the deregulation of the higher education market in Peru. We recognized that this process began with the enactment of Law No. 26439 establishing the National Council for the Authorization for Operation of Universities (CONAFU).

The process of deregulation in the higher education market allowed the identification of university quality in our empirical strategy to the extent that: (i) it results in the expansion of the supply of universities and (ii) leads to a decline in university quality offered by functioning institutions. The validity of both assumptions is further analyzed and tested in this paper. Regarding this process, Balarín (2013) points out a college market deregulation promoted by the issue of the Legislative Decree No. 882 which approved the Law of Investment Promotion in Education (LIPE) in 1997. This law allowed the authorization of education institutions 
(including universities) to operate with or without profit purposes. Beforehand, the Act No. 26439 approved in January 1995 the creation of CONAFU. This organization replaced the National Congressional Committee and the Ministry of Education in the function of approving the operation of universities in the country. For our estimations, we identified the CONAFU creation date as the beginning of the deregulation in the college market due to reasons explained in later sections. The resulting legal framework set by LIPE and CONAFU increased the number of education ventures eligible to be universities for which they decreased entry barriers that enabled a rapid admittance to the higher education market. The evolution of operating universities after the creation of CONAFU provides evidence that support the validity of this first assumption: 45 universities began to operate in the post-deregulation scenario, among which 70.3\% (i.e., 34 universities) have «lower quality» — according to the operational definition of lower and higher quality institutions used throughout this paper. Slightly less than half (45\%) of the universities operating up to 2010 launched after the market deregulation. This group of institutions is characterized mostly by low tuition fees that aim to attract emerging sectors of the population (see Yamada et al 2013, Yamada \& Castro 2013).

Then, based on a measure of university quality (made from six indicators or components) we found that universities that arose afterward the deregulation had a lower quality score compared to institutions previously launched. Our result confirms the validity of the second identification assumption by giving evidence that the global distribution of university quality started heading a «lower bound». To the best of our knowledge, this is the first study that attempts to empirically measure college quality of the supply of universities in its entirety and not to be restricted to the top or a sub group 3 . We expect that this contribution will serve for a broader discussion of university policies in the country, since quality measures previously developed (e.g. Piscoya 2006, American Economy 2010, 2012, 2013) focused on the country's leading universities and did not address lower quality universities that require more monitoring in recent years.

Within the institutional context described, a first discrete choice model allowed us to estimate the probability (conditional on financial constraints and socioeconomic characteristics) by which university population chooses «lower quality» universities. For the pre deregulation period, the average probability was estimated at 0.64 based on the CENAUN 1996 dataset; while for the post-deregulation period, the student population in the CENAUN 2010 dataset had an average conditional probability of 0.71 . These results point out that the probability of attending a «lower quality» college is higher in the post-deregulation period. Then, the central model of discrete level of academics that make up a sample estimate obtained from the ENAHO choice for the period 2004-2012 is proposed. The variable of interest is the power quality college predicted from the results of estimation of the first stage. Thus, the first model is necessary to reconstruct the variable of interest to

\footnotetext{
${ }^{3}$ The American Economic rankings do not cover all higher education institutions. In particular, they do not evaluate universities of lesser quality because they do not report information.
} 
attend a college of "lower quality" from a prediction, since the name of the university from which he graduated in the sample estimate is not reported professionals.

Evaluating only the effect of the expansion of universities in the market it was estimated that, when exposed to the pre-deregulation university offer, college graduates of «lower quality» institutions are about 1.19 times more likely to be underemployed. Additionally, evaluating both the effect of the expansion of universities and restricted access to higher education for students with lower skills in the pre-deregulation period, we documented that to have attended to a «lower quality» university is associated with a probability 1.2 times greater of being underemployed. On these results, we find that the propensity to be underemployed, such that an individual attended to «lower quality» universities, increased after deregulation since they are 1.30 times more likely to be underemployed.

Deregulation of the higher education market has allowed the entry of universities with a relatively lower quality with respect to existing universities in the pre deregulation stage. At the individual level of every college applicant, we propose that this event increased the odds of entering colleges, making the student more likely to receive less quality training. We hold as hypothesis that through both results described, the process of deregulation that took place in the college market has been transmitted to the labor market as a contributor to the increase in professional employment.

The paper is organized as follows. Section two presents a literature review of the methods for measuring professional underemployment as well as the main empirical studies addressing the relationship between university quality and working conditions achieved by professionals. Section 3 characterizes the process of deregulation and its impact on the supply and quality of universities. Similarly, describes the main features of the evolution of professional employment. Section 4 details the data used in the estimates. Section 5 provides the empirical strategy to measure the effects of attending a college of lower quality on the underemployment; while Section 6 develops the empirical model proposed by quantifying the ratio of interest from exogenous variation in college quality. Also, the validity of the source of variation is discussed and presents the findings of empirical estimation. Finally, Section 7 summarizes the results and conclusions.

\section{Literature review}

\section{Professional underemployment: Definition and consequences}

Professional underemployment has been defined in the international literature from a variety of perspectives and associated with each one, arise a specific cause for this phenomena. Vedder, Matgouranis, et al. (2010) address professional underemployment in the United States as the condition for which an individual performs job vacancies that are predominantly occupied by those with relatively lower levels of educational attainment, 
i.e., lower years of education. The authors bring together university graduates with such characteristics under the term «over-educated». Using information from the Department of Labor of the United States results warn that US underemployment rate stood at $38 \%$ in 2008.

The status of over-educated is the dimension of underemployment that has been addressed more extensively in both theoretical and empirical studies. McGuinness \& Doyle (2004) analyze its effects on the distribution of wage earnings of college graduates in Northern Ireland who entered the higher education system between 1991 and 1992. Using the quintiles regression method, they find that the wage penalty for «over-educated» women is greater than that of men (almost double). Also, even though the impacts on men tend to be concentrated in the segment of the wage distribution that is usually associated with lower levels of skill, the effects associated to women proved to be more extensive and constant throughout the entire distribution wage. The authors also pointed that educational background and regional labor market characteristics have an important role in the expansion of the gender wage gap.

Similarly, McGuiness (2006) notes that over-educated workers tend to have lower returns to education compared to employees with the same educational level but with jobs commensurate with their college training. Meanwhile, Alba-Ramirez (1993) shows that over-educated workers stay for shorter periods in work places and have a lower average job training time, in contrast to their non-over-educated counterparts. Among other predominantly empirical works addressing the consequences of underemployment for over-education in terms of wages and productivity, stand those of Hartog \& Tsang (1989), Handel (2003), Badillo-Amador et al. (2005) and Di Pietro and Urwin (2006).

Academic research conducted for Peru also address the concept of professional underemployment from various perspectives. Arregui (1993) uses the term «inadequate job» to refer to the underemployment condition by which there is a discordance between the undertaken occupation and the college education received (discipline or career) that prevents the individual from the full use of their acquired qualifications. In other words, the underemployed are those performing non-professional occupations. For the period extending from 1986 to 1991, the author finds that university graduates had less chance to obtain a proper job or one according to their abilities in contrast to graduates of higher education at a technical level.

Verdera (1995) proposes a definition and calculation method of underemployment based on the work of Klein (1988) and Farooq $(1986)^{4}$. The author identifies a need to consider the skills in the definition of

\footnotetext{
${ }^{4}$ The author provides two tables of double entry: (a) one with educational levels and career groups, (b) another with occupation for which a worker and occupational groups prepared. Then in both tables a "cutoff level" is stablished by which the author considers that there is correspondence between the level of education or training for work reached with the occupational groups in which workers perform are defined. This cutoff level is represented in both tables by a diagonal line where the area above indicates underutilization of skills workers.
} 
underemployment, for which it uses the term «disguised underemployment». This is defined as the underutilization of the qualified members of the Economically Active Population (EAP) when they are employed in an occupational group with lower qualification requirement. The mismatch between training (skills) and occupation (requirements) is defined in two ways: by level of education attained (e.g. technical, college, graduate) and according to the occupation for which the employee was formed (e.g. career). As such, the definition incorporates elements of measuring underemployment under the terms of over-education and occupational mismatch. Study results indicate that between 1991 and 1993 «disguised underemployment» by education level increased from 36\% to 40\%; and underemployment according to the preparation for assigned work, decreased from 35\% to 32\%. Moreover, it was identified that «disguised underemployment» increased for individuals with technical training during the period 1991-1992; while it increased for those trained to office jobs from 1992 to 1993.

The issue of underemployment is taken up by Burga \& Moreno (2001), who applied a measurement strategy based on Clog et al. (1984) to capture the phenomenon of over-education in Peru, as well as the mismatch between the profession and occupation in urban areas using data from the 1997 ENAHO. Among their findings it is shown that $44 \%$ of individuals with university education in occupations for which they did not received an adequate training and 35\% are over-educated — with more years of education required for their work. The authors also study the consequences of being over-educated by which college graduates earn wage incomes about 20\% higher than those «properly educated» (which means not over or sub educated). Also, the mismatch condition between college career and occupation has negative effects on labor income: a professional employee in an occupation for which he or she has not received formal education is paid $33 \%$ less.

Second, the professional underemployment is a threat that potentially distorts investment in education as a mechanism for upward social mobilization (see Benavides 2004). In this regard, Benavides \& Etesse (2012) compared the occupations held by fathers and their children from the ENAHO 2008 for a sample of about 3,000 chiefs of household. The occupational categories proposed are blue-collar workers, professional groups, merchants and dependent employees. Their methodology measures the association degree between occupational groups of origin (for the father) and destination (corresponding to children) with a unidiff model. The authors conclude that intergenerational occupational mobility is greater when the children completed higher education studies. However, in this context the underemployment condition (as proposed herein) may prevent intergenerational upward mobility, to the extent that prevents graduates to attain groups of professional employees. This empirical evidence suggests that urges the equalizing effect of opportunity that ideally would promote higher education is being hampered by underemployment. 


\section{University quality}

Among the items assessed as plausible causes of the underemployment, the literature has seen its relationship with the quality of university education. Similarly in underemployment literature, studies addressing this phenomenon by relating it to university quality are not based on a unique concept of quality. A range of educational and employment outcomes are used as indicators of university quality to the extent that are associated with a broad definition, which involves meeting the following objectives: the purpose of education and remuneration of the returns to higher education (see Harvey \& Knight, 1993).

McGuinness (2006) provides empirical evidence on the relationship between underemployment and college quality information of university entrants in Northern Ireland for 1991, matched with an index of college quality. The results show that the average earnings of attending a higher quality university tend to be limited. Moreover, impacts on the quality of employment and wage income were limited to particular disciplines graduates or those who obtained degrees from universities considered «good quality». After controlling for precollege entrance attributes, labor market outcomes for most graduates depended more on race classification studied and obtained title to the college you attended.

Milla (2012) estimates wage returns of institutional prestige and quality of Canadian universities using two university rankings. The first is the Global ranking of Best Overall Reputation issued in Maclean magazine; the second is a university ranking built by the author. Information on hourly wages earned in the first job of undergraduate graduates — de the Youth in Transition Survey (Youth in Transition Survey) is used. The research concludes that the premium for graduating in a university from the top $25 \%$ ranking, compared to one located in the bottom $25 \%$, it is $15.2 \%$ for women and $29.9 \%$ for men. Thus, reputation premium of the college are generally higher for men than for women.

Case studies for Peru do not explicitly assess the quality as the cause of professional employment to date. However there are important precedents. Gautier (2012) gives a reading of the political and cultural elements that have resulted in a mass higher education, a process which, as noted, has not been accompanied by an evolution in the quality of education. Meanwhile, quantitative studies such as Yamada \& Castro (2013) and Yamada et al. (2013) suggest that although a higher proportion of the population has access to university education in the country, the quality of education services has declined. Nevertheless, the authors fail to separate the exaggerated increase in the coverage of the evolution of university quality. Additionally, the selectivity of universities as an approach to educational quality is addressed. Yamada et al. (2013) notes from the year 2000 a deterioration of skills of college students, measured by the Skills and Peruvian Labour Market Survey of 2010 (ENHAB). This trend, coupled with the lower selectivity in admission is proposed as an important accomplice of the worsening of university quality. 
In a similar vein, Diaz \& Jaramillo (2008) discuss the relationship between underemployment and quality of higher education. The authors note that post-secondary studies are important mechanisms for increasing productivity and for social mobilization, given the limitations of the basic general education. However, the heterogeneity of quality universities and institutes causes a divergence between the skills of the labor force and labor demand, making it difficult to reap the benefits of higher education.

In short, potential effects of any progress (or worsening) in university quality over gradutes' labor market outcomes is an area of research that remains relatively underdeveloped in developing countries and the Peruvian case. The existing literature does not specifically address this relationship — specifically the linkage to income and future working conditions - which is important to explore as it influences the decision of many young people opting for higher education or not, as well as the selection of the institution to be attended. The context of marked increase in professional underemployment rates in Peru commends to analyze the role of the quality of higher education as a possible cause of this phenomenon; especially since the common believe that every university leads to job success, spreads in the country. Also, the definition of professional underemployment is perceived as fragmented in the literature, focusing on a variety of aspects that characterize a disadvantageous employment status but do not reach a comprehensive concept. Nor is there an adequate concept to describe the phenomenon in the country, considering the characteristics of the local labor market, graduates and prospective applicants to higher education. As such, there is particular interest in this paper to provide empirical evidence on the causal relationship of college quality and professional underemployment, so that the definitions that measure both are relevant to the Peruvian case.

\section{Stylized facts}

\subsection{Deregulation of higher education}

A new legal framework that regulates market entry of institutions of higher education was introduced in January 1995 with the creation of the National Council for the Authorization for Operation of Universities (CONAFU) Law No. 26439). This autonomous agency of the National Assembly of Rectors (ANR) was commissioned to assess and issue legal resolutions authorizing or disapproving projects and operating license applications for new universities nationwide. Prior to the establishment of this institution, universities could only be created or deleted by rule of law. These norms were evaluated by the Ministry of Education and a committee in Congress, as determined by the predecessor University Act (No. 23733) from 1983. According to this Act, those interested in the creation of universities had to demonstrate the need for the creation of the

entity and the availability of qualified teachers and to ensure the efficiency of its services resources. However, 
with the creation of CONAFU during the nineties, the authorization of new universities depended on the approval of the members of this new council.

Another highlight what constitutes the «Law to Promote Investment in Education» (LPIE) issued by Legislative Decree No. 882 in January 1997. The feature that deserves attention with respect to this law is the authorization of private institutions of higher education to be promoted, conducted and managed nonprofit latter - being new in relation to previous standards. Since then, every natural or legal person has the right to free private initiative to organize educational institutions, which involves the establishment of educational systems, the determination of the duration of study programs among other things, provided they meet the requirements minimum of the Ministry of Education. This new regulation replaced the previously issued Law No. 23733 which established private universities could only be introduced by a legal person governed by private law and nonprofit. In the previous context, surplus arising at the end of the financial year could only be invested on behalf of the institution or for scholarships. The funds could not be distributed to shareholders or board members and could not be used by them directly or indirectly. By contrast, the LPIE allows the distribution of surplus among investors of a particular university.

The purpose of this second law was promoting job creation in the economy, the support for private investment in education services and the modernization and expansion of the education system. However, institutional changes in the higher education market may have resulted in some educational enterprises that undermine those objectives. More specifically, as a result of the new regime, numerous legal entry barriers to higher education institutions we taken down significantly. As proof, the ANR records indicate that at present there are 140 universities across the country ${ }^{5}$. A major period of expansion of universities began around 1997: in a period of ten years from then (1997 to 2007) 35 universities were created and in the next five years (20082012) 47 additional universities were launched as shown in Figure II located on page 13. Similarly, the number of applicants and students enrolled in the university system maintains a growing trend as noted in Figure I. the average annual enrollment growth was $1.2 \%$ in the pre deregulation from 1985 to 1997, while in the post deregulation period 1998-2012 amounts to 6.5\%. These last two periods of expansion of universities and enrolled students, which took place subsequent to the law creating the CONAFU and issuance of DL 882, may have influenced the increase in the underemployment rate for the period 2000-2012. We formulate the hypothesis that the contribution to underemployment by universities depends on the quality of educational services provided; whether they were created before or after the new legal scheme initiated by the creation of CONAFU and configured by both standards described. The validity of this relationship is discussed in Section 6.

\footnotetext{
${ }^{5}$ They are not included in the analysis the Faculty of Theology and 4 Graduate Schools registered by the NRA. However, all the institutionalized process of institutionalization and universities are included.
} 


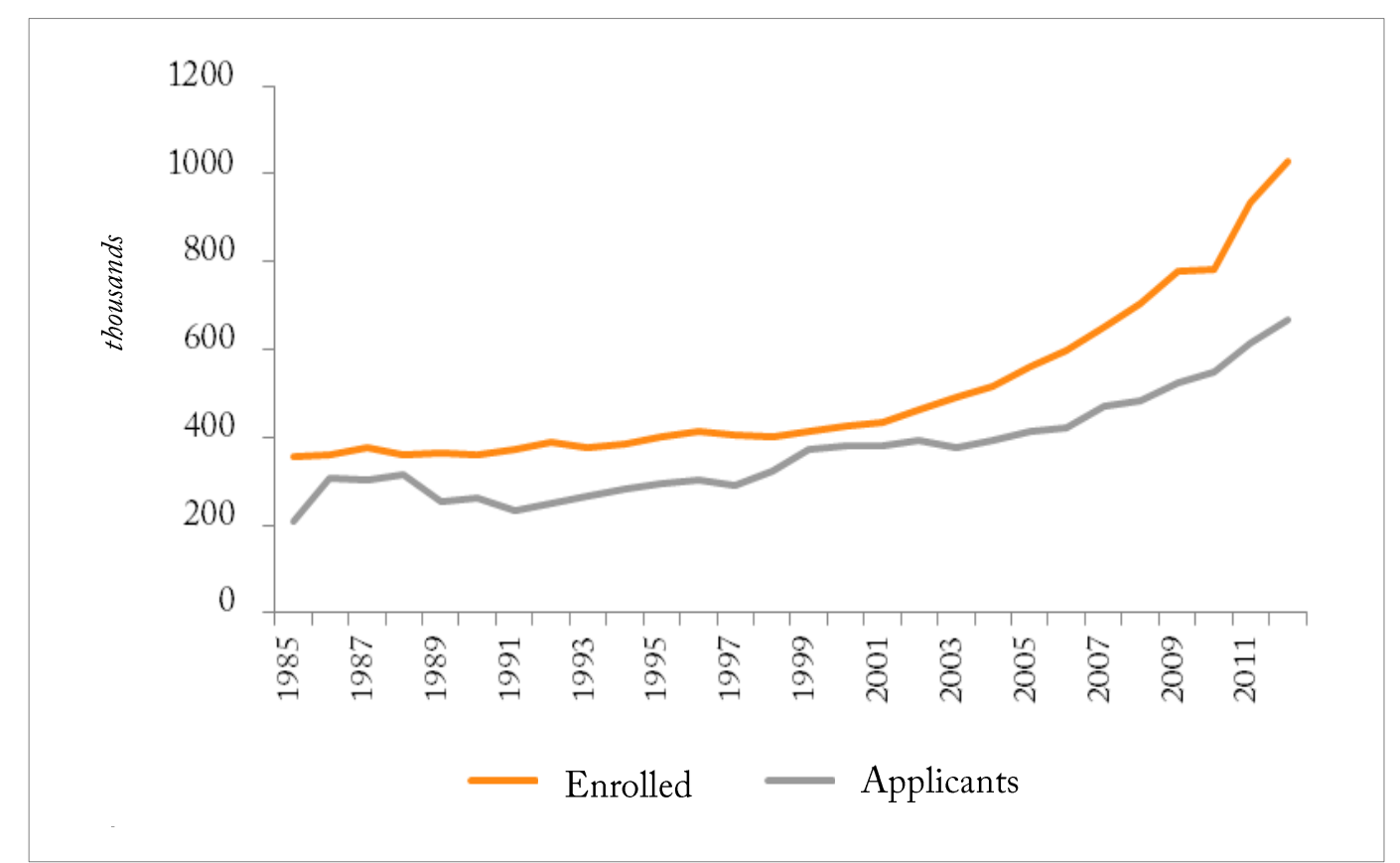

Figure I.- Number of enrolled students and applicants, by year (1985-2012). Source: Department of Statistics of the National Assembly of Rectors. 


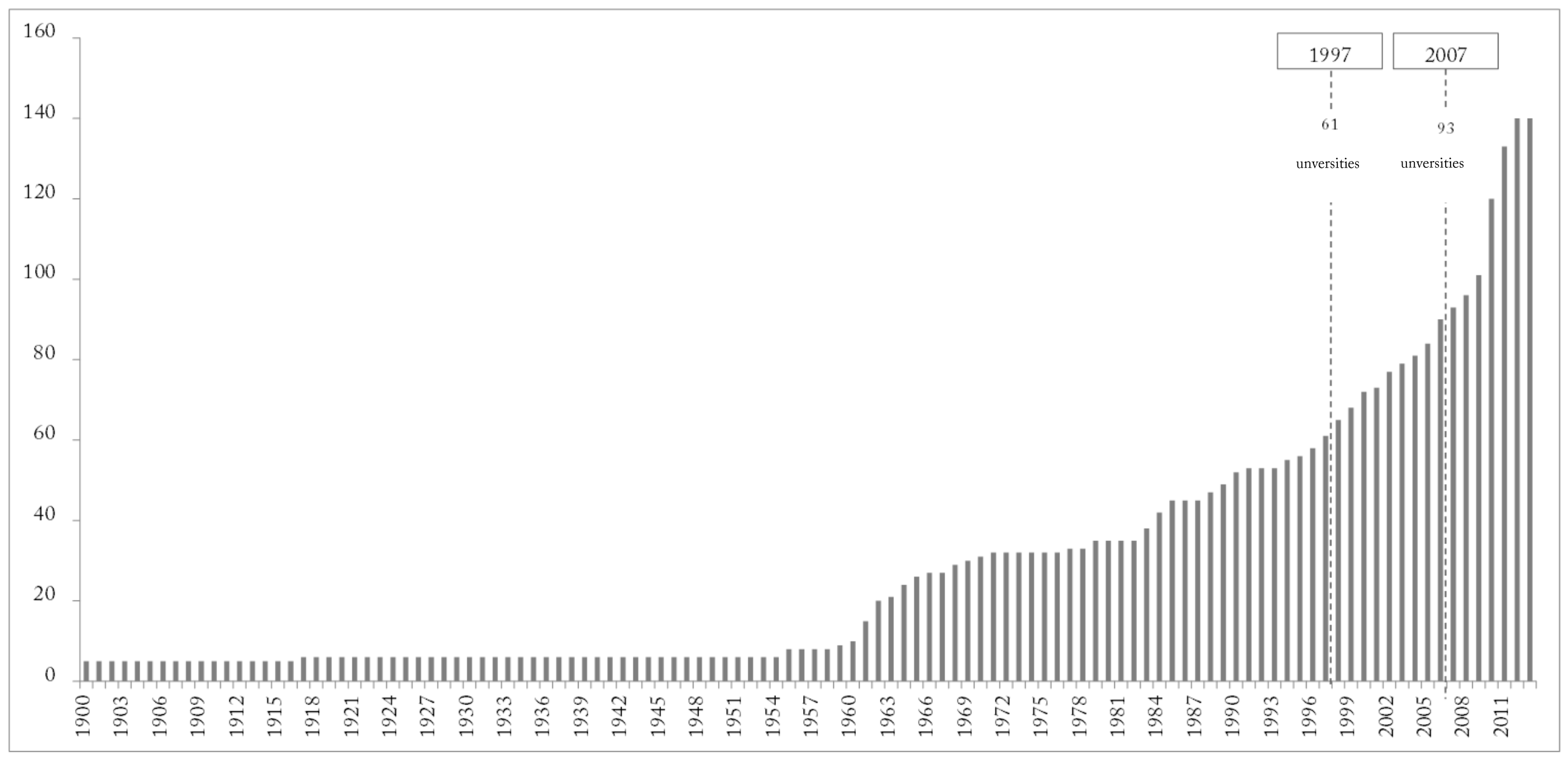

Figure II.- Number of public and private universities operating by year (1900-2011). Classification based on the statutory records of the date of creation.

Source: Department of Statistics of the National Assembly of Rectors. 


\subsection{Definition of professional underemployment}

The employment indicator that plausibly captures the effects of deregulation of the higher education market in Peru (reviewed in the previous section) is the professional employment rate. We analyze this phenomenon at the aggregate and individual level for which this section discusses the definition of commercial underemployment to be used throughout the study. This is the cornerstone of the assumptions and stylized facts on the dynamics of underemployment as described in section 3.3. We propose two definitions of professional underemployment: one «strict» and another «flexible». The main objective is to address the complexity of the phenomenon of professional underemployment proposing a definition that encompasses the main aspects of the problem. This will survive a feature of the literature of underemployment that tends to show focusing on one aspect: the limitations imposed on wages (see, e.g. Sicherman 1991 Groot 2000, McGuinness 2004) or the mismatch between higher education and the work done (Leuven \& Oosterbeek 2011, Sahin et al., 2011). Moreover, this global definition allows working in a modeling environment in which we are allowed to test a wider set of underemployment determinants —among them, university quality. The «strict» definition requires the fulfillment of the three conditions listed below; while the «flexible» definition requires the first two to categorize individuals as underemployed.

The expanded estimation pooled sample, which was used to calculate the rate of underemployment, has a total 5.2 million college graduates employed in the National Household Survey of Peru (ENAHO) for the period from 2004 to $2012^{6}$. From the total sample of occupied professionals ${ }^{7}$ we considered for estimation purposes to those who at the time of the survey had the following characteristics: (i) belong to the range of 24 to 65 years, (ii) work full time or more 35 hours a week, (iii) are regular members of the household in which they were surveyed (excludes domestic workers, visitors, etc.) and (iv) live in urban areas at the time of the survey. Graduates who were studying at the time of the survey and those who belong to the top of bottom $1 \%$ on the income distribution from each occupational group, is excluded. Neither the members of the occupational groups that have less than 30 observations were considered. Each occupational group defined two-digit level of the International Standard Classification of Occupations ${ }^{8}$ (ISCO) proposed by the ILO and modified for use in the country by INEI.

\footnotetext{
${ }^{6}$ The sample estimate for 2004 is 422,000 graduates working for 2005 is 418,000; for 2006 is 532 thousand for 2007 is 601,000, the year 2008 is 572 thousand for the year 2009 is 636,000, the year 2010 is 605,000, the year 2011 is 645,000 and for 2012 is summarized 736,000 graduates working.

${ }^{7}$ The operational definition of professionals includes individuals who report having a college degree or higher degree in the survey, we restrict estimation sample whose graduates working and living conditions expose underemployment.

${ }^{8}$ In English, International Standard Occupation Classification (ISOC).
} 
For the estimation sample described ${ }^{9}$, the proposed definition of «strict professional underemployment» implies the fulfillment of three conditions simultaneously. These are summarized in Table XVI in Appendix I. First, it requires that the individual is an underemployed educated professional ${ }^{10}$ : a condition characterized by having more full years of schooling required to carry out a professional activity. This state aims to identify cases in which the graduates are working in jobs for which their formal education is greater than that required, either because they work in jobs not related to education (e.g., business managers work as baristas) or activities related to their education, but what they do not need as much training (in the case of MBA graduates who work as bank tellers). Specifically, we note that over-educated graduates are those with college education complete with number of years of schooling achieved (usually 16 for college graduates in Peru ${ }^{11}$ ) are above the threshold calculated within an occupational group. These thresholds are calculated as the average number of years of schooling for the occupational group standard deviation. Our empirical approach to evaluate this condition follows the strategy of calculation for the case of Peru by Burga \& Moreno (2001) and the original methodological proposal Clog et al. (1984). This method is used to estimate a threshold that allows the identification of over-educated individuals within their respective occupational group (see Table XVII in Appendix I). Our calculation takes the average number of years of schooling as a substitute for required years of schooling that will give a person the possibility of having an occupation that is consistent with their education in a particular field.

When applied to the ENAHO, the average years of schooling held by graduates within an occupational group ISCO at a 2-digit level reflects the average needs of formal education by the productive sector. We rely on the fact that compliance with this average level of university education allows a college graduate holding a job. Used as a reference point, the average year of schooling is used to identify people in three categories: overeducated, properly trained and under educated .

According to this methodology, underemployed professionals are relatively over-educated regarding the occupational category for which they are working. A main feature of this measure is that it depends on the size of the entire distribution of people within a professional group at a 2-digit level. Since the composition of the reference group changes over time, the estimated threshold only considers the professional workforce available in a given year. Remarkably, the extent of over-education proposal does not involve nor based on a relationship between the number of years of education and productivity levels. Therefore, it does not follow that overeducated graduates are necessarily supra or infra productive in their jobs.

\footnotetext{
${ }^{9}$ The full description of the estimation sample used to calculate the rate of underemployment is described in Section 5.

${ }^{10}$ Among others, see Leuven and Oosterbeek (2011), McGuinness (2006), Groot et al. (2000) and Alba-Raj (1993).

${ }^{11}$ Careers offered in Peruvian universities have an average duration of five years to be added to the eleven years of basic schooling (primary and secondary).
} 
The second condition of professional underemployment relates graduates who are employed in nonprofessional occupations that do not require a bachelor's degree (see Table XVIII in Appendix I). In the case of Peru, there is no official classification to distinguish precisely what occupations may or may not require such degree. However, the occupations in the ENAHO survey are classified based on ISCO codes, which provide an important input for our calculation. Based on the approach and the processing of ISCO codes made by Sahin et al. (2011), we transformed the ENAHO to a 1-digit level. As a result, we have a classification of economic activities in Peru that require a college degree and those who do not require it.

The third condition implies that a graduate is classified as sub paid in the respective career group ${ }^{12}$ (see Table XIX classification, Appendix I). Through a Mincer equation, we estimated the average wage conditional on the number of years of higher education that is particular to each professional group, minus one standard deviation - see Appendix II to the method of calculation. We use these thresholds to distinguish between adequately paid graduates and those who are not. These thresholds reflect the net income that a graduate must earn on average given their educational and socio-demographic characteristics (professional experience, the management of the institution attended, gender, marital status, place of residence, etc.). So, a sub paid graduate has hourly earnings which put he or she below a paying threshold associated to his or her career.

To conclude, Figure VIII in Appendix I summarizes all the conditions included in the «strict» and «flexible» definition of underemployment. Graduates who do not meet the three conditions simultaneously are not considered underemployed graduates under the «strict» definition. However, if they meet the first two conditions are classified as underemployed according to the «flexible» definition we propose. For example, those who are overeducated and working in a non-professional occupation, but are overpaid under-employed do not qualify as an underemployed professional under the «strict» definition, but they do under the «flexible» definition. The figure in the appendix describes all the functions whose combinations give rise to situations of professional employment.

\subsection{Recent trend of professional underemployment}

\section{Panorama professional underemployment, 2007-2012}

In this section, the main objective is to analyze the latest trends in underemployment among university graduates in Peru, as well as showing the factors behind its increase. In particular, we are interested in capturing the effects of a change in the legal regime by which more universities began their operations in Peru. It has been hypothesized that deregulation of the market for higher education is one of the major contributors

\footnotetext{
${ }^{12}$ The proposed career groups are: Economics; Other Engineering and Natural Sciences; Law; Humanities and Social Sciences, Medicine and Racing related; Other careers related to Health and Education.
} 
to the rapid growth of professional underemployment and also allows the identification of the change in the overall quality of educational institutions for the purposes of our empirical strategy. For this reason, we seek to clarify the effects of the laws in study on higher education market and the labor market.

In the latter instance, the most obvious result of the expansion of the supply of university education is the relatively high rate of underemployment during this period of economic prosperity for the country -in which a downward trend is expected (Yamada et al. 2013). There was a recovery in the workforce or professional EAP from 2001 to 2012 that resulted in a cumulative growth of $33 \%$ of professional workforce equivalent to more than 276 thousand graduates (see Table XXIV, Appendix III). In this context, underemployment stands out as a new problem to consider. In fact, the phenomenon of underemployment has relegated attention once exercised towards the occupational unemployment rate in Peru, which has fallen from $8 \%$ in 2006 to $5 \%$ in 2012 (see Figure IV). In contrast, the prevalence of professional underemployment reached its peak in the last decade in 2011. In this year, according to our definition of «flexible» professional underemployment, $43 \%$ of graduates employed 24 to 65 years of age and working full time were underemployed, while according to the «strict» definition almost 31\% were underemployed. As shown in Figure III, both statistics slightly decreased during the following year.

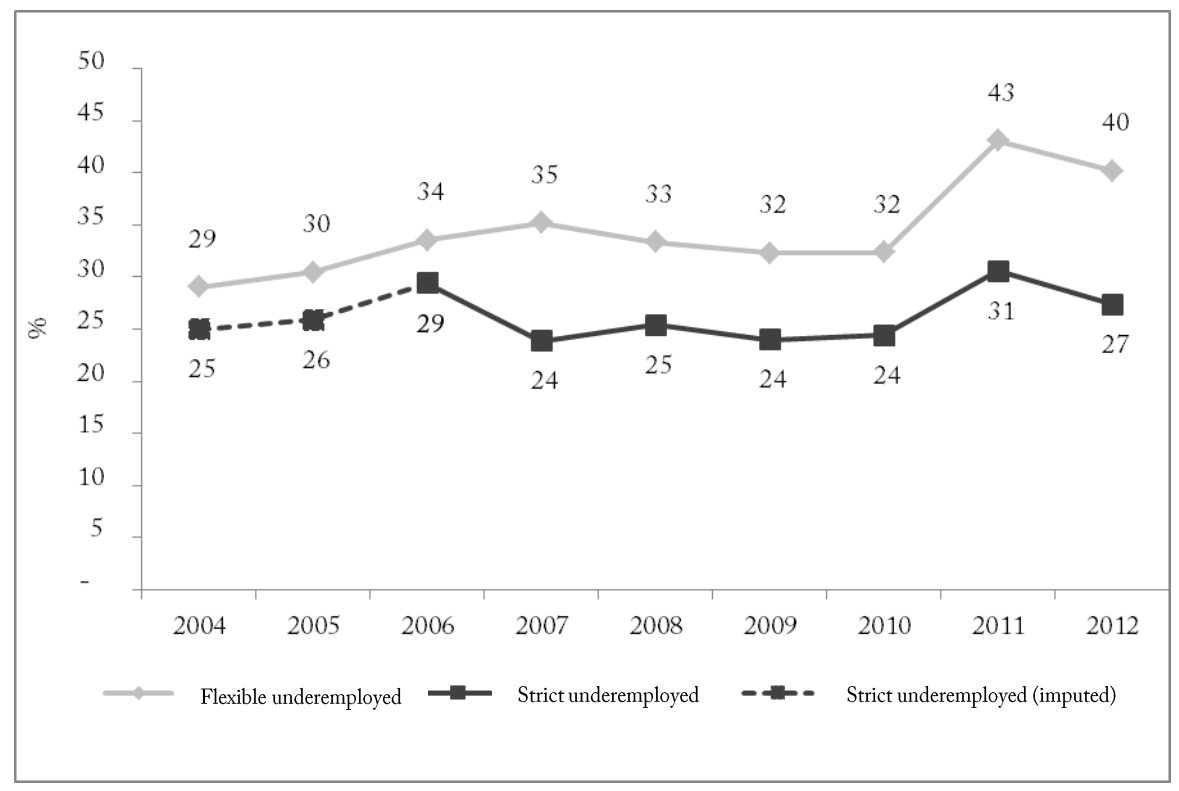

Figure III.- Evolution of professional underemployment in EAP. Percentage of college graduates 24 to 65 , employed full time.

Source: ENAHO Survey 2004-2012. Notes: (1) Professional EAP includes college graduates 24 to 65 years. Residents living in rural areas or not ordinary residents interviewed households are excluded from the sample. (2) The strict underemployment entails overeducated graduates occupied in non-professional occupations and underpaid graduates; while the flexible underemployment considers only the first two conditions. (3) The thresholds of average hourly pay, required for the calculation of strict underemployment are not available for 2004-2006 and correspond to an average of the thresholds calculated for the period 2007-2012. So underemployment rates for the period are presented in reference mode. 
From a general look at the whole issue of professional underemployment, Table I shows that the global supply of graduates ${ }^{13}$ had an annual growth rate of $6.4 \%$ for the period 2004 to 2012 . This exceeds the pace of job creation not involving underemployment among professionals - whose average growth rate was 4.4\%, according to the «flexible» definition, and $2.6 \%$, according to the «strict» definition. The results under both definitions, flexible and strict, for the period 2007-2012 indicate the same trend: the yearly income of graduates in the labor market is more dynamic than the average capacity of the productive sector to properly employ these professionals.

Table I: Growth rate of the demand and supply of professional EAP

(percent variation)

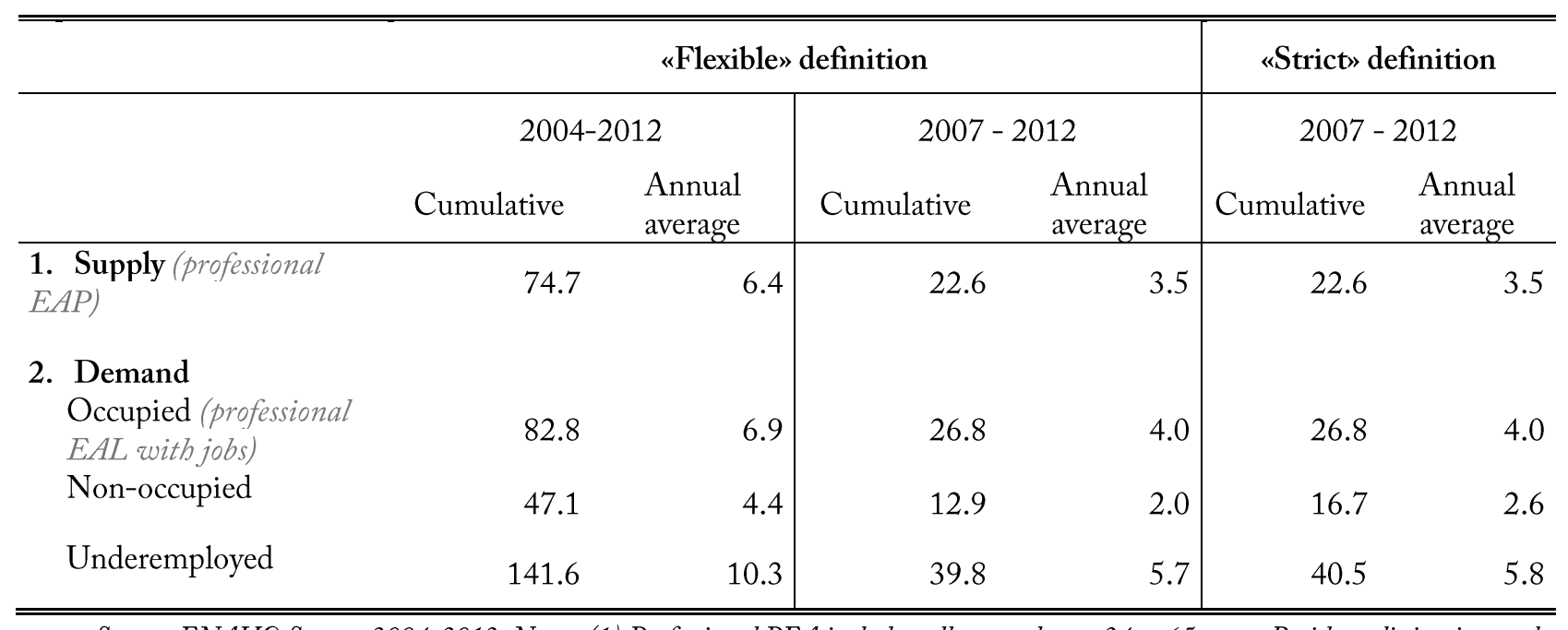

Source: ENAHO Survey 2004-2012. Notes: (1) Professional PEA includes college graduates 24 to 65 years. Residents living in rural areas or not ordinary residents interviewed households are excluded from the sample. (2) The strict underemployment entails overeducated graduates occupied in non-professional occupations and underpaid graduates; while the flexible underemployment considers only the first two conditions.

The revised gap between the growth rate of the number of graduates and the rate of creation of adequate employment reveals a non-trivial result, if we focus on the distribution of this trend among career families, as detailed in Table II. The demand for graduates trained in the following career clusters: Economics, Humanities and Social Sciences and Natural Sciences and Engineering show the most growth - average rates of annual growth of $12.7 \%, 9.3 \%$ and $85 \%$ respectively for the period 2007-2012. However, this growth in demand covers both vacancies involving underemployed and not underemployed. Both the flexible as strict definition of underemployment draw two professional groups such as the fastest growing underemployment: Humanities and Social Sciences; and Economics. Consequently, much of the growth in demand of these professional groups falls into the category of professional employment.

${ }^{13}$ We measure labor supply as professional workforce or professional EAP. 
Table II: Growth of professional demand, by career family

(2007-2012)

\begin{tabular}{|c|c|c|c|c|c|c|}
\hline & \multirow{2}{*}{\multicolumn{2}{|c|}{$\begin{array}{c}\text { Underemployment: } \\
\text { flexible } \\
\% \text { var. }\end{array}$}} & \multirow{2}{*}{\multicolumn{2}{|c|}{$\begin{array}{c}\text { Underemployment: } \\
\text { strict } \\
\% \text { var. }\end{array}$}} & \multicolumn{2}{|c|}{ Total demand } \\
\hline & & & & & $\%$ & \\
\hline & Cumulative & $\begin{array}{l}\text { Annual } \\
\text { average }\end{array}$ & Cumulative & $\begin{array}{l}\text { Annual } \\
\text { average }\end{array}$ & Cumulative & $\begin{array}{l}\text { Annual } \\
\text { average }\end{array}$ \\
\hline $\begin{array}{l}\text { Economics and } \\
\text { business }\end{array}$ & 91.5 & 11.4 & 87.1 & 11.0 & 105.3 & 12.7 \\
\hline $\begin{array}{l}\text { Engineering and } \\
\text { natural sciences }\end{array}$ & 88.8 & 11.2 & 77.1 & 10.0 & 63.1 & 8.5 \\
\hline Law & 30.8 & 4.6 & -0.7 & -0.1 & 54.4 & 7.5 \\
\hline $\begin{array}{l}\text { Social sciences and } \\
\text { humanities }\end{array}$ & 183.5 & 19.0 & 105.6 & 12.8 & 70.2 & 9.3 \\
\hline Medicine and health & -40.7 & -8.3 & -59.4 & -13.9 & 48.8 & 6.8 \\
\hline Other health careers & 195.4 & 19.8 & 207.3 & 20.6 & 24.6 & 3.7 \\
\hline Education & 99.9 & 12.2 & 39.6 & 5.7 & 37.5 & 5.5 \\
\hline Other careers & 382.1 & 30.0 & 346.9 & 28.3 & 134.2 & 15.2 \\
\hline
\end{tabular}

Source: ENAHO Survey 2004-2012. Notes: (1) Professional PEA includes college graduates 24 to 65 years. Residents living in rural areas or not ordinary residents interviewed households are excluded from the sample. (2) The strict underemployment entails overeducated graduates occupied in non-professional occupations and underpaid graduates; while the flexible underemployment considers only the first two conditions.

In summary, our analysis of labor demand distinguishes between jobs that involve the status of underemployed and adequately employed professional - the latter is defined as not being underemployed. We verified that there is evidence of excessive and concentrated professional supply in certain career groups in Peru for the period 2007-2012. Such disparity possibly has been invigorated by a reading of the professional demand that does not adequately distinguish between underemployed and adequately employed individuals. This may be leading to an overestimation of the actual production needs of professionals formed in universities. The following sections provide a more detailed look at the trends described in this section is given.

\section{Prevalence and distribution of underemployment}

The evolution of professional underemployment is embedded in the dynamics of the workforce formed by college graduates - those with completed university education or who have masters university studies. Professional EAP from 24 to 65 years-old working full-time and part-time at the national level was comprised of approximately 1.29 million individuals in 2012. This represents an increase of professional workforce equivalent to $52 \%$ (cumulative change) with respect to 2001 levels. As shown in Figure IV, a high percentage 
of this group (92\% on average each year from 2001 to 2012) is occupied and only an average of 75 thousand professionals is unemployed each year from analyzed ${ }^{14}$.

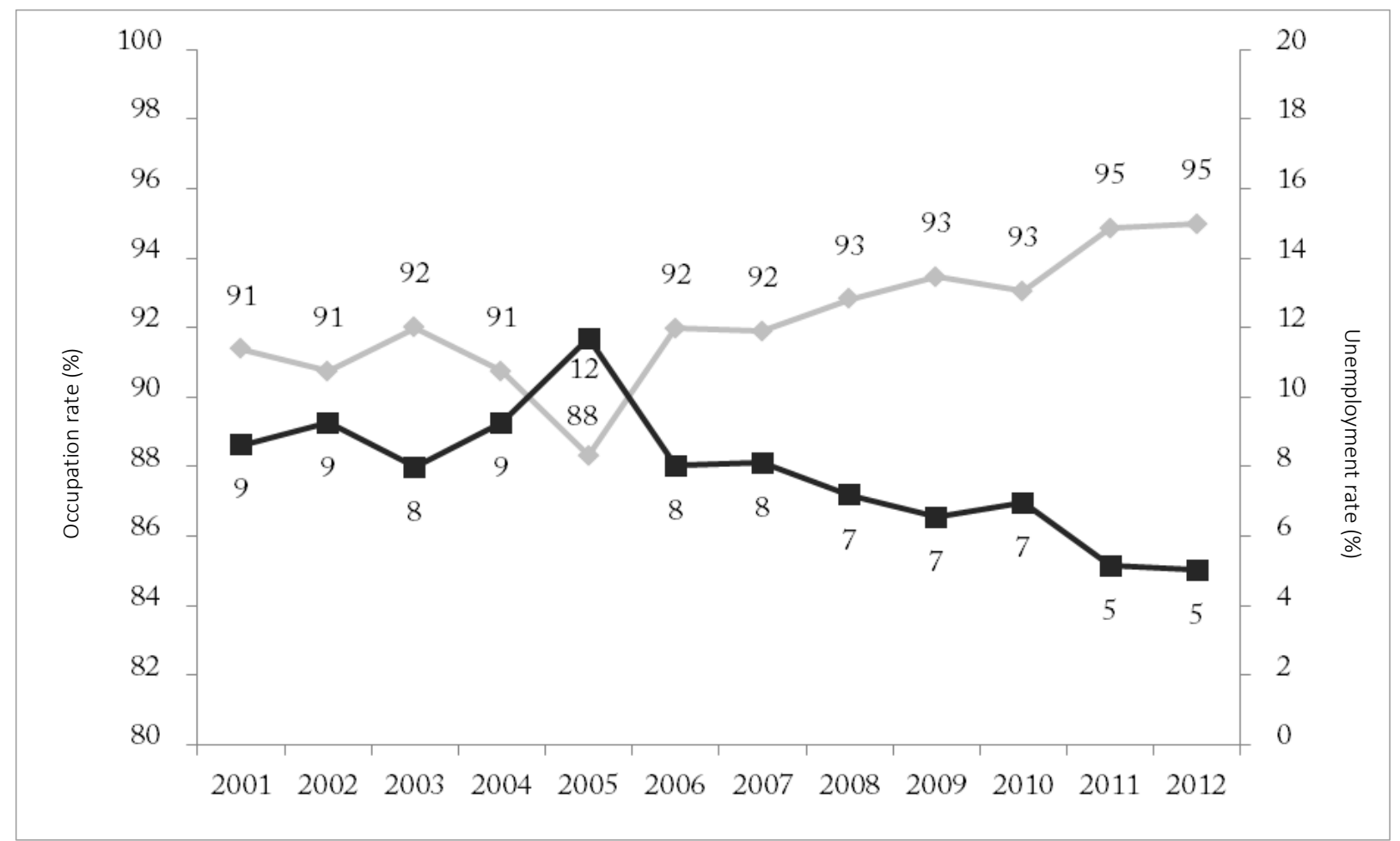

Figure IV: Employment and unemployment rates among professional EAP. Percentage of college graduates 24 to 65 , employed full or part time

Source: ENAHO Survey 2004-2012. Notes: (1) Professional PEA includes college graduates 24 to 65 years. Residents living in rural areas or not ordinary residents interviewed households are excluded from the sample. (2) The strict underemployment entails overeducated graduates occupied in non-professional occupations and underpaid graduates; while the flexible underemployment considers only the first two conditions.

With the increasing development of professional underemployment revised the previous subsection, we seek to identify which sector of the economy has contributed most to this trend. For this, we will focus only on the professional full-time worker. According to the «flexible definition» of professional underemployment, the Agriculture, Hunting and Forestry as well as Trade sector have the highest prevalence in the analyzed years of 2007 and 2012. About 70\% of professionals employed in the Trade sector in the year 2007 are underemployed; a number increases in 2012 and reaches 75\%. It is observed in Figure V, that between 2007 and 2012, the system of economic sectors that contribute most to underemployment is altered. In 2012 he first has to Agriculture, Hunting and Forestry (where 81\% of full-time professional PEA corresponds to underemployed), second in importance is Commerce; then Manufacturing (45\%), construction (41\%), services (32\%) and

\footnotetext{
${ }^{14}$ Consider that data gathering for the ENAHO survey is performed in stages throughout the year, so reports of occupational status (employed or unemployed) provided by the survey are subject seasonality.
} 
construction (28\%) on. In contrast, in 2007 the Trade industry occupied first place in importance (70\% underemployed professionals), followed by agriculture, hunting and forestry (61\%) and the following sectors. Notably, the construction sector had the highest increase in the rate of underemployed professionals, from $20 \%$ in 2007 to $41 \%$ in 2012.

The order found is consistent with the level of professional training and specialization required job vacancies in each of these sectors. For example, it is less likely for an individual employed in the mining sector to fall into professional underemployment as is being defined, because this sector often asks for very specific qualifications in relation to the appointment of qualified staff due to standards tasks or the specialization degree. This suggests that the lower the employer's ability to relax the required skills for the jobs, the lower the probability of underemployment.

Following the strict definition of professional underemployment, Figure V shows that the prevalence of underemployed in each economic sector also declines to consider how adequate the total labor income they receive is. The most dramatic reduction was seen in the mining sector in 2012, as $25 \%$ of underemployed in that sector with «flexible» definition is passed that only $6 \%$ of professionals employed in the sector are categorized as underemployed. This trend is contrary to that found in the analysis under the «flexible» definition of underemployment: here the prevalence rose 5 percentage points. This indicates that in 2012, 22\% of professionals employed in the mining sector are over educated and working in an occupation for which no college degree is required; yet their earnings are high enough not to qualify as underemployed. A similar pattern was detected in the other productive sectors, especially the case of Agriculture, where 34\% of overeducated graduates and occupied in nonprofessional occupations, sub are not paid and therefore do not enter the classification of strict underemployment. 
Figure V: Professional underemployment distribution by economic activity -strict and flexible definition

(Percentage of university graduates working full-time, between 24-65 years)
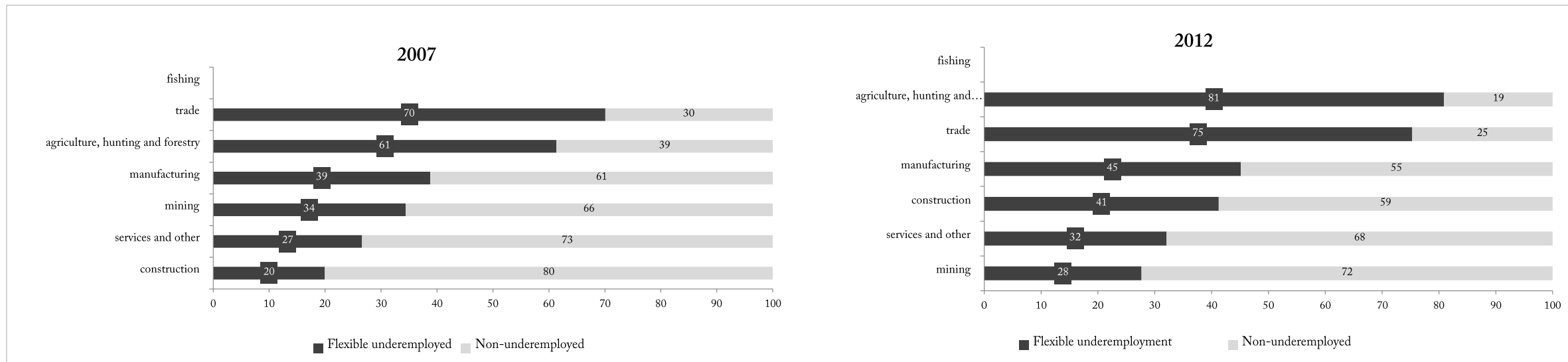

2007

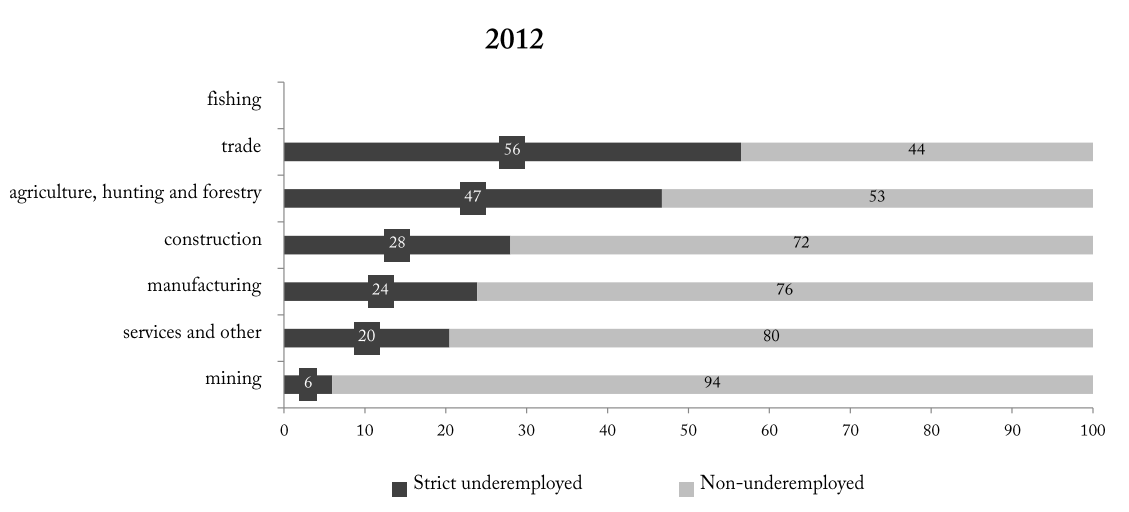

Source: ENAHO Survey 2004 - 2012 Notes: (1) Residents living in rural areas or not ordinary residents interviewed households are excluded from the sample. (2) The strict underemployment of educated graduates alos found in non-professional occupations and underpaid; Flexible underemployment considers nly the first two conditions 
In assessing the distribution of underemployment by career groups in Figure VI, the one that has a higher percentage of underemployed according to the «flexible» definition is Economics and Business Sciences with 54\% and 50\% prevalence in 2007 and 2012 respectively. The next most important career group is the one of those who does not report their profession ${ }^{15}$. Another important group of careers which contribute largely to underemployment is the Humanities and Social Sciences, which is registered as the area with the highest number of underemployed in 2012 with about $68 \%$ of underemployed on total employment in the sector.

Under the strict definition of underemployment, it is seen at the bottom of Figure VI that the sector Economics and Business Sciences is positioned as the main contributor to professional underemployment in 2007, to the extent that professionals with this kind of university education fall in this condition by 35\%. Meanwhile, by 2012 the careers of Humanities and Social Sciences have the highest prevalence of underemployed professionals (38\%), followed in importance by the branch of Economics and Business Sciences (32\%) and Engineering and Other Sciences. Both categories are noted as those more saturated and in which, possibly, vocational supply has over-passed the level of demand from the productive sector. As such, vacancies of suitable jobs (in terms of skills requirements and earnings) are met by professionals in these careers; however, there is an oversupply of professionals in these branches that, for lack of better prospects for their training exercise, fall in underemployment. For its part, the races belonging to the category of Other Careers related to Health, Medicine and Health, Education and Law have the lowest levels of prevalence of underemployment.

\footnotetext{
${ }^{15}$ In 2007, the group of individuals who do not mention their careers as members of the category of Other careers were not reported neither considered. In subsequent years, all individuals in the sample reported their profession.
} 
Figure VI: Underemployment racing family - and strict flexible definition

(percentage of university graduates working full-time, between 24-65 years)

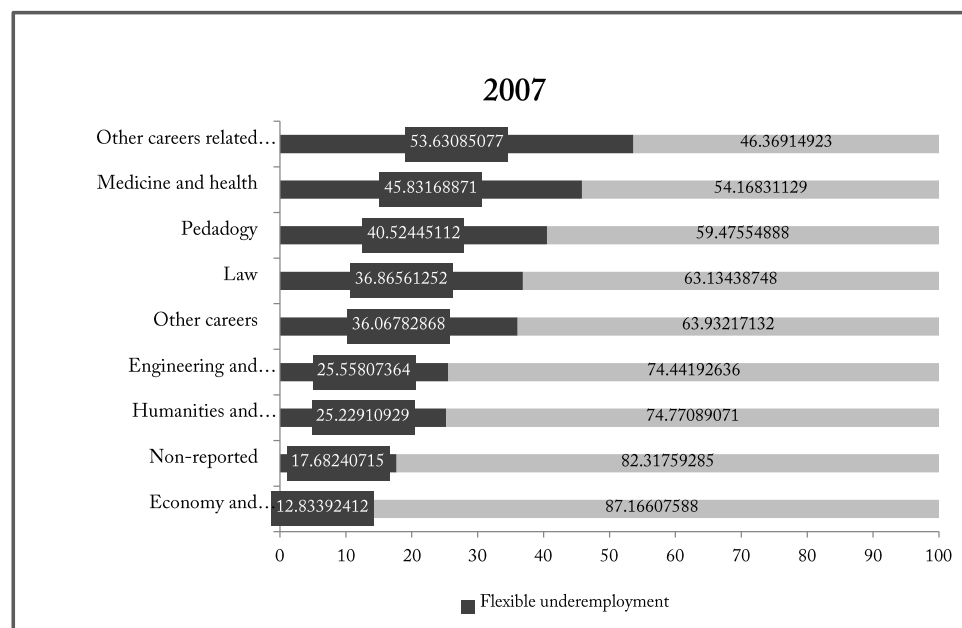

2012

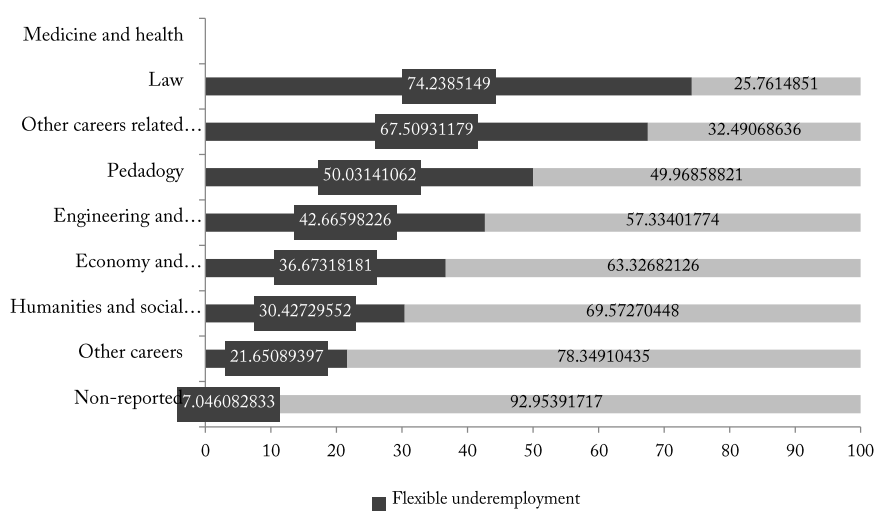

2007

2012
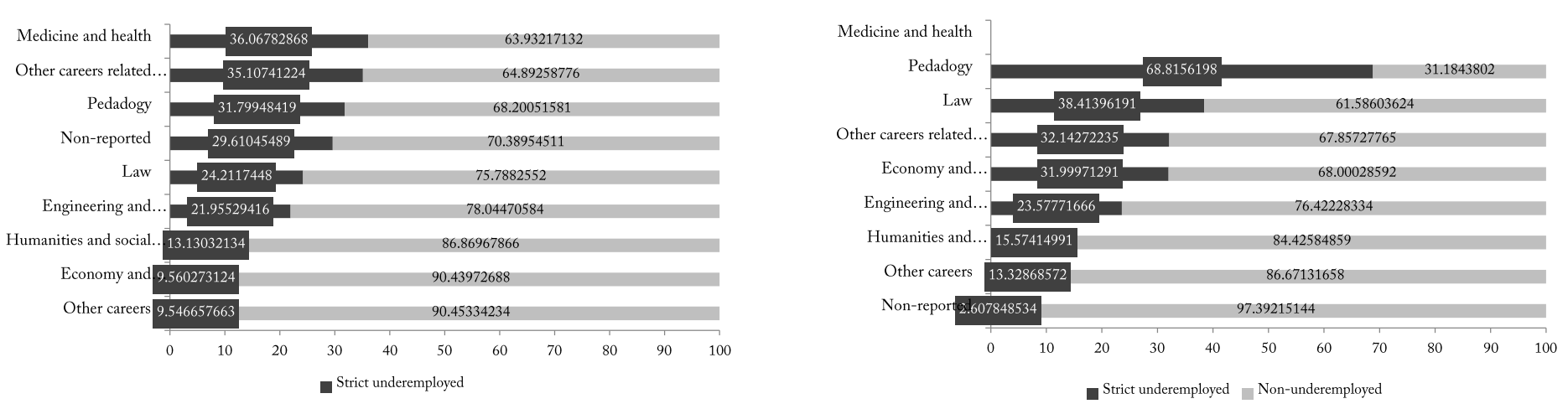

Source: ENAHO Survey 2004 - 2012. Notes: (1) Residents living in rural areas or not ordinary residents interviewed households are excluded from the sample. (2) The strict underemployment of educated graduates alos found in non-professional occupations and underpaid; Flexible underemployment considers nly the first two conditions 
The last aspect to analyze is the distribution of underemployment by «skills profiles» required in professional jobs. Based on the classification developed by Sahin et al. (2011) where exists four profiles associated with each occupation, we elaborated a harmonization with ISCO occupational codes for Peru (see Table XX in Appendix I). From these categories, Figure VII shows, with bars that start in the left, the percentage of underemployed professionals, while bars starting in the right axis indicate the percentage of non-under-employed or not adequately employed professionals. For both years analyzed and both definitions of underemployment, it is observed that those occupations classified as Manual/Routine have the highest prevalence of underemployment; followed in importance and Cognitive/Routine occupations. In contrast, the occupations Manuals/No routine and Cognitive/No routine have lower prevalence flexible underemployment (with a prevalence of 59\% and 1\%, respectively) and strict (with prevalence of 34 and 1\%, respectively) in 2012.

According to the «strict» definition, the previously observed pattern is the same for both years analyzed. In the bottom of Figure VII shows up occupations Manual/Routine and Cognitive/Routine home to the largest number of underemployed in 2012 -around 106 thousand and 126 thousand, respectively according to the flexible employment. On the contrary, No Routine occupations are home to only 31 thousand underemployed professionals in total. Analyzing both profiles Routine occupations, we observed an increase in the prevalence of underemployed equivalent to 37\% or 62 thousand professionals between 2007 and 2012 indicated. This evolution gives evidence of a change of skills profiles demanded by companies, which decreased their demand occupations Manual/Routine used properly (23 p.) and Cognitive/Routine (3 pp.).

\section{Labor income underemployed}

In this section, total labor income earned underemployed professionals and employees are properly analyzed. Income considers both analyzed as labor earnings of the main and secondary occupations. As shown in Table III (page 28), the income of underemployed professionals are located below the wages of professionals not underemployed in each year of the 2007-2012 period and for both definitions of underemployment.

In this section, total labor income earned underemployed professionals and employees were properly analyzed. Income considers both labor earnings of the main and secondary occupations. As shown in Table III (page 28), the income of underemployed professionals are located below the wages of professionals who are not underemployed in each year of the 2007-2012 period and for both definitions of underemployment. 
Figure VII: Underemployment skill profile - and strict flexible definition

(percentage of university graduates working full and part time, between 24-65 years)
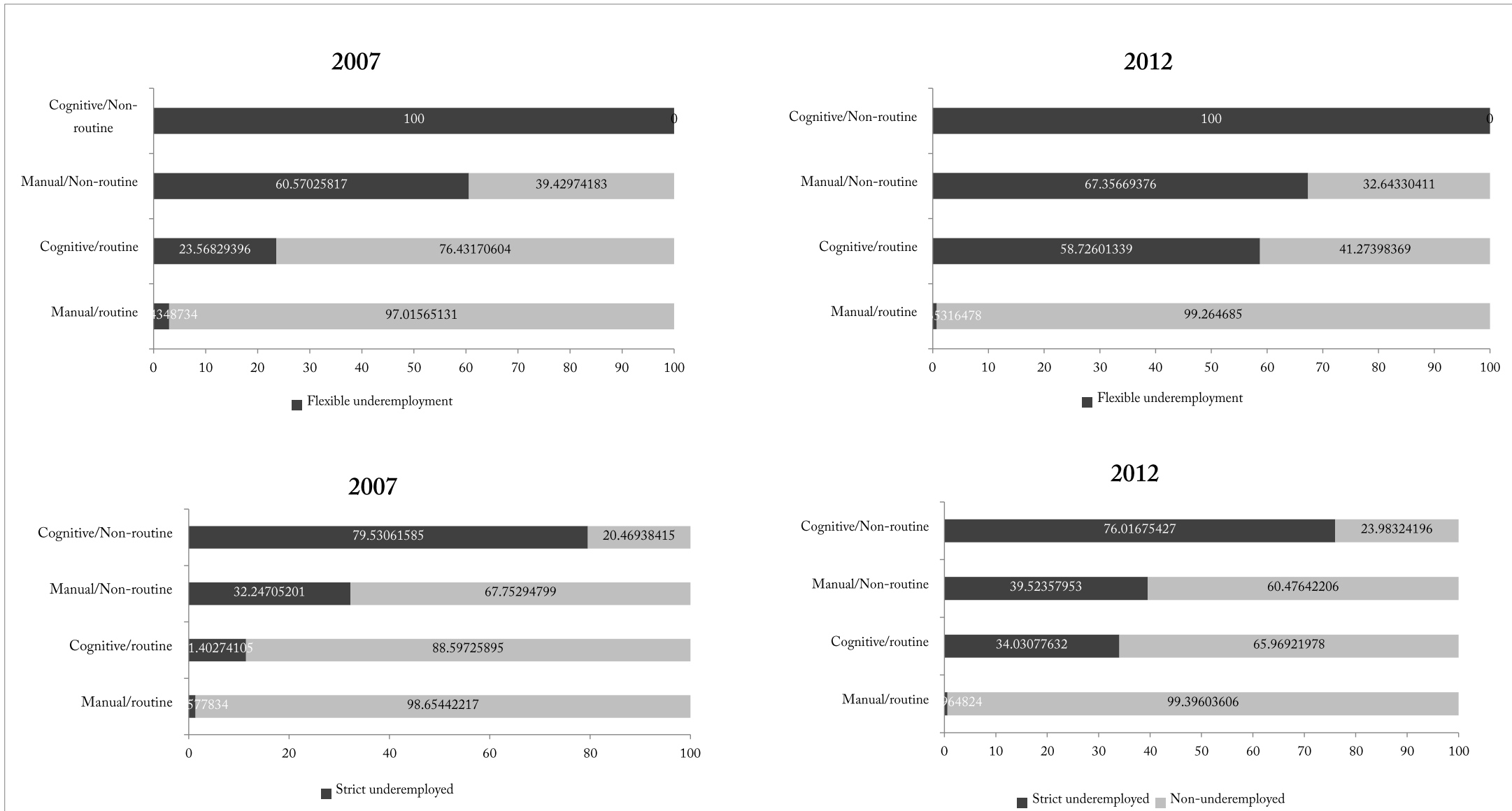

Source: ENAHO Survey 2004 - 2012. Notes: (1) Residents living in rural areas or not ordinary residents interviewed households are excluded from the sample. (2) The strict underemployment of educated graduates alos found in non-professional occupations and underpaid; Flexible underemployment considers nly the first two conditions 
According to the flexible definition of professional underemployment, during the reporting period net labor earnings of underemployed professionals are on average $23 \%$ lower than adequately underemployed professionals. During 2012, the income gap peaked described, to the extent that the wages of underemployed professionals were $28 \%$ lower than those employees properly. When analyzing the strict underemployment, we note that professional employees can properly earning up to 1.5 times higher than those of underemployed professionals, as in 2009 when the labor income gap peaked.

Table III: Evolution of gross monthly income, employment status (annual deflated peruvian soles from 2009)

\begin{tabular}{|c|c|c|c|c|c|}
\hline & \multicolumn{2}{|c|}{ Subempleado: definición flexible } & \multicolumn{2}{|c|}{ Subempleado: definición estricta } & \multirow{2}{*}{$\begin{array}{c}\text { Profesionales } \\
\text { ocupados }\end{array}$} \\
\hline & $\begin{array}{c}\text { No } \\
\text { subempleado }\end{array}$ & Subempleado & $\begin{array}{c}\text { No } \\
\text { subempleado } \\
\end{array}$ & Subempleado & \\
\hline \multirow{2}{*}{2007} & 1,774 & 1,433 & 1,902 & 837.96 & 1,654 \\
\hline & $(2,190)$ & $(1,485)$ & $(2,171)$ & $(624)$ & $(1,978)$ \\
\hline \multirow{2}{*}{2008} & 1,841 & 1,467 & 1,987 & 884.48 & 1,716 \\
\hline & $(1,784)$ & $(1,474)$ & $(1,842)$ & $(622)$ & $(1,696)$ \\
\hline \multirow{2}{*}{2009} & 2,059 & 1,531 & 2,195 & 877.12 & 1,889 \\
\hline & $(2,553)$ & $(1,863)$ & $(2,609)$ & $(511)$ & $(2,365)$ \\
\hline \multirow{2}{*}{2010} & 1,846 & 1,442 & 1,962 & 923.15 & 1,715 \\
\hline & $(1,714)$ & $(1,390)$ & $(1,764)$ & $(576)$ & $(1,627)$ \\
\hline \multirow{2}{*}{2011} & 2,066 & 1,590 & 2,215 & $1,014.08$ & 1,861 \\
\hline & $(2,409)$ & $(1,639)$ & $(2,417)$ & $(571)$ & $(2,125)$ \\
\hline \multirow{2}{*}{2012} & 2,311 & 1,667 & 2,413 & $1,030.38$ & 2,052 \\
\hline & $(2,981)$ & $(1,895)$ & $(2,942)$ & $(594)$ & $(2,619)$ \\
\hline
\end{tabular}

Source: The Survey 2007 - 2012. Notes: Residents living in rural areas or not ordinary residents interviewed households are excluded from the sample. Standard deviations are in parentheses.

By looking for the 2012 career groups in Table IV, the average earnings of underemployed professionals under the flexible definition are below the income of those adequately employed for all groups except Other Health Careers. Significantly, in all cases, except the Law, Economics and Business Sciences and Pedagogy these differences are statistically significant with confidence levels of $90 \%$ and $95 \%$. In absolute terms, the differences in earnings locate between 70 and 2,377 peruvian soles that correspond to Pedagogy and Law, respectively. Professionals dedicated to pedagogy have the lowest level of income in case of being underemployed —earning 1,219 peruvian soles on average. Among careers with earnings that have significant differences, stand out the careers of Humanities and Social Sciences where underemployed professionals earn about 1,100 peruvian soles less that those adequately employed. This observation is consistent with the high influx of professionals from these disciplines into the labor market as noted at the beginning of this section. It is also expected that the wage gap in this career group will be rising as more professionals in these disciplines enter the labor market with a high probability to fall in underemployment. Despite the large gaps identified, there are also careers in 
which the earnings of underemployed professionals bear no excessive difference with their peers adequately employed: Medicine and health, other careers and Pedagogy.

Recall that by definition, the classification of «strict» underemployment considers as an additional condition to be underemployed, that individuals should be located below wage thresholds equivalent to conditional means of labor income by main occupations, controlling for individual characteristics (e.g. gender) and work-related (e.g. industry). Then, when considering the average income based on this definition, we note that wage differences are statistically significant with a confidence level of 99\%; and range from 520 soles (Other Health Careers) and 2,800 soles (Law). In the case of the latter career family, underemployed professionals have 61\% less revenue than their peers who are employed properly. Also differs significantly the underemployed within the Humanities and Social Sciences and Natural Sciences and Engineering career groups, earning 44\% and 27\% less than their counterpart, respectively.

Then, according to the economic sector in which develop the «strict» underemployed, their wage gap with respect to those not underemployed range from 1,190 peruvian soles in the case of Other Services to 3,800 soles in the case of Agriculture, bunting and forestry. These differences are statistically significant, as well as those between the incomes of professionals that are adequately employed in Manufacturing and Constructions sectors, who earn 1.2 and 1.9 times mores, respectively. In conclusion, the wage gap between non underemployed and underemployed are present at the expense of the latter group, under both definitions proposed for professional employment. These gaps have increased in correlation with the rate of underemployment professional, showing higher in 2011 and 2012. Also the wage premium of those employed properly is magnified or decreased depending on the professional career that has been followed and the economic activity that the individual is performing. Careers with greater differences in income coincide with those having a greater flow of professionals in the market - according to the results seen in the previous section. As well, graduates for careers of Humanities and Social Sciences and Law are identified as doubly vulnerable under the definition of flexible underemployment, since the high propensity to fall into this condition implies that are over educated and work in non-professional occupations; and due to the low wage returns they receive. 
Table IV: Levels of gross monthly income, 2012

(annually deflated soles of 2009)

\begin{tabular}{|c|c|c|c|c|c|c|c|c|c|c|c|c|}
\hline & \multicolumn{6}{|c|}{ Underemployed: flexible definition } & \multicolumn{6}{|c|}{ Underemployed: strict definition } \\
\hline & \multicolumn{2}{|c|}{ Non-underemployed } & \multicolumn{2}{|c|}{ Underemployed } & \multicolumn{2}{|c|}{ Average difference } & \multicolumn{2}{|c|}{$\begin{array}{c}\text { Non- } \\
\text { underemployed }\end{array}$} & \multicolumn{2}{|c|}{ Underemployed } & \multicolumn{2}{|c|}{$\begin{array}{l}\text { Average } \\
\text { difference }\end{array}$} \\
\hline & Mean & S.D. & Mean & S.D. & Dif. & $\mathrm{p}$-value & Mean & S.D. & Mean & S.D. & Dif. & p-value \\
\hline 1. Career groups & & & & & & & & & & & & \\
\hline Economics and business & 1,993 & 1,233 & 1,775 & 1,647 & 218 & 0.469 & 2,274 & 1,571 & 1,055 & 628 & 1,219 & 0.000 \\
\hline $\begin{array}{l}\text { Engineering and natural } \\
\text { sciences }\end{array}$ & 2,575 & 2,163 & 1,885 & 2,428 & 689 & 0.002 & 2,820 & 2,605 & 1,142 & 546 & 1,677 & 0.000 \\
\hline Law & 3,879 & 7,275 & 1,502 & 1,252 & 2,377 & 0.111 & 3,805 & 7,027 & 973 & 396 & 2,833 & 0.019 \\
\hline $\begin{array}{l}\text { Humanities and social } \\
\text { sciences }\end{array}$ & 2,505 & 2,131 & 1,402 & 983 & 1,103 & 0.019 & 2,348 & 1,672 & 817 & 558 & 1,531 & 0.000 \\
\hline Medicine and health & 2,470 & 1,596 & 2,303 & 1,051 & 168 & 0.077 & 2,499 & 1,565 & 949 & 263 & 1,550 & 0.033 \\
\hline Other health careers & 1,433 & 580 & 1,514 & 1,213 & $\overline{8}$ & 0.043 & 1,580 & 784 & 1,060 & 837 & 521 & 0.000 \\
\hline Pedagogy & 1,292 & 1,121 & 1,219 & 1,049 & 73 & 0.144 & 1,381 & 1,127 & 514 & 313 & 867 & 0.000 \\
\hline Others & 3,739 & - & 1,823 & 873 & 1,917 & . & 3,898 & 345 & 1,599 & 375 & 2,298 & 0.004 \\
\hline 2. Economic activities & & & & & & & & & & & & \\
\hline $\begin{array}{l}\text { Agriculture, hunting and } \\
\text { forestry }\end{array}$ & 2,042 & 698 & 2,262 & 3,668 & $\begin{array}{c}- \\
220\end{array}$ & 0.936 & 4,035 & 3,680 & 151 & 172 & 3,884 & 0.012 \\
\hline Mining & 3,167 & 1,672 & 2,868 & 1,020 & 298 & . & 3,204 & 1,494 & 1,197 & 202 & 2,007 & . \\
\hline Manufacture & 2,268 & 1,384 & 1,689 & 1,038 & 579 & 0.054 & 2,308 & 1,282 & 1,046 & 578 & 1,262 & 0.003 \\
\hline Construction & 2,812 & 1,883 & 2,369 & 5,630 & 443 & 0.004 & 3,222 & 4,450 & 1,102 & 372 & 2,120 & 0.000 \\
\hline Trade & 2,865 & 2,653 & 1,577 & 1,696 & 1,288 & 0.700 & 3,111 & 2,540 & 960 & 692 & 2,151 & 0.052 \\
\hline Services and others & 2,225 & 3,202 & 1,609 & 1,260 & 616 & 0.000 & 2,271 & 3,022 & 1,079 & 539 & 1,192 & 0.000 \\
\hline Total & 2,311 & 2,981 & 1,667 & 1,895 & 416 & - & 2,413 & 2,942 & 1,030 & 594 & 1,383 & - \\
\hline
\end{tabular}

Source: ENAHO Survey 2004 - 2012 Note: Residents living in rural areas or not ordinary residents interviewed households are excluded from the sample. Dots indicate that no information is available; however, the data lines are not calculated. 


\section{Data and estimation sample}

Throughout the study, two data sources are used in the absence of availability of a nationally representative survey that contains retrospective information on higher educational path of university graduates with the name of the university of origin besides job performance variables. To date, the specific name of the college attended by members of the professional PEA is collected in regular surveys addressing labor and educational variables. The bases used in this study will be described in the order of calculations and estimates.

First, to measure the quality of universities, the National University Census (CENAUN) compiled by the National Institute of Statistics and Informatics (INEI) in 1996 and 2010. Both censuses contain information on college students, faculty and facilities used fifty-three (53) identified regional universities in 1996 and ninety-six (96) identified in 2010. Regarding undergraduate students and teachers, information on living conditions, academic achievement, financial constraints, research and a qualitative assessment of the college you attend or where they work is collected. This information is derived from surveys directly to students and teachers. This type of self-report combined with the lack of verification of the information provided, allows us to anticipate an upbeat testimony in variables related to educational quality -over all related to teacher performance ${ }^{16}$. Moreover, an inventory of the assets of each campus is also available in both university censuses. This information is reported by administrative staff of universities evaluated and to our knowledge, is not subject to any type of confirmation. For complete information on universities, the National Assembly of Rectors (ANR) offers the founding date of each educational institution. This allowed us to identify the legal framework in which universities were created.

In the first stage of our analysis, we focus on the quality of the universities that have entered in the higher education market after the deregulation, compared to institutions of higher education previously created. In section 3.1 it was stated that the deregulation process is comprised by the creation of CONAFU (Law No. 26439) and the issuance of LPIE (DL No. 882). As such, we propose that the date from which the deregulation process is evaluated matches the date of issue of the Law establishing the CONAFU. Thus, for calculations realized in forward, the pre-deregulation period runs until January 21, 1995 while the postderegulation period runs from 22 January 1995 until 2010 —during which, the II University Census was collected.

To specify how the expansion of the supply of universities affected underemployment, an unbiased measurement of the quality of each university is required. Since this variable is not reported on rankings issued

\footnotetext{
${ }^{16}$ This is a limitation of the information collected in the CENAUN in both years, to the extent that the information reported is subject omissions or unreliable reports because of the conflict of interest posed by the questionnaire.
} 
by government agencies or by an official source in Peru, we value it from a set of six indicators. The proposed indicators are based on assessment of Piscoya (2006) and in the group of variables used by the Ranking of Best Universities of Peru American Economy (2013). We seek to measure three major aspects of university quality: (i) the employability of undergraduate students, the (ii) the resources of the teachers and the (iii) the academic standards. On the initial set of indicators covering the aspects described, we selected those that were collected in both censuses and in which there is minor probability of over-reporting ${ }^{17}$. In this exercise the information was used at a university level. From the previous considerations, the proposed quality indicators are: (1) the ratio of teachers per hundred undergraduate students ${ }^{18}$; (2) the percentage of students scoring good or excellent level of university education ${ }^{19}$; (3) the percentage of teachers with research disseminated in books for two years prior to survey; (4) the score of the documents published in academic journals indexed by SCOPUS ${ }^{20}$; (5) The percentage of regular and contract teachers attended as speakers scientists or academic events; and (6) the ratio of papers published in academic journals per hundred teachers.

Then, to model the attendance at a university or higher quality low, two samples of college students reported in the census are used: (a) one with individuals exposed to the supply of pre-deregulation universities $(\mathrm{N}=322$ 805, the CENAUN 1996); and (b) a second sample to individuals exposed to the university offer postderegulation ( $N=739$ 479, CEAUN 2010). In the first sample individuals who entered before 1996 are maintained; while in the second it keeps those who entered from 1996 to 2010. While the month of January 1995 (hereinafter referred to as "court date") was defined as the start date for the deregulation of the market, we believe valid to evaluate university quality assessment a year later under the following assumptions: (i) the quality of educational institutions remained relatively constant over the period of one year, so in 1996 the measurement is sufficiently similar to a 1995 (ii) the 1996 Census contains information from six universities created after the cutoff date, however, students attending these universities represent only $3.6 \%$ of the total sample (11, 400 students).

Second, for calculations related to the tendency of professional underemployment data on college graduates was obtained from the National Household Survey in Peru (ENAHO) for the period 2001-2012. The variables used to calculate estimated underemployment rates were available only for the period of 2004-2012,

\footnotetext{
${ }^{17}$ The criterion in this selection consisted of using indicators that were not depending on the report of individual activities (e.g. Number of hours devoted to teaching, number of training last year) but that capture quality at an aggregate level based on variables over which is unlikely for individuals to make judgments about how they would affect his survey (e.g. ratio of number of students per teacher).

${ }^{18}$ The faculty members involved are those hired permanently by universities. This excludes extraordinary or honor teachers.

${ }^{19} \mathrm{It}$ is necessary to highlight that the CENAUN 1996 relates to the prospects of a college education, while from 2010 Census refers to university education received.

${ }^{20}$ The documents published from 2003 to 2007 are considered to measure the lack of quality due 1996 for previous years.
} 
as explained in Section 3.2. For these years the professional underemployment was calculated with representation at national and regional level.

Besides the calculation of underemployment in the aggregate, the sample of university professionals ENAHO was used to explore the central relationship of the study: the effect of university quality on underemployment. Thus, the condition of underemployed, under the strict and flexible definitions, was computed individually for all EAP professional university occupied for the period 2007-2012. Both variables are alternative measures of the dependent variable. The variable of interest is dichotomous type that takes the value of one $(=1)$ when the individual has a high probability of attending a college of lower quality and zero $(=0)$ when not. The first case is identified with the case where the individual actually attends a college of "lower quality" while the second corresponds to assistance to institutions of "higher quality". The threshold used to dichotomize this probability in both categories ('higher quality' and 'lower quality') in section 6, because it requires familiarity with all stages of the empirical estimation are described.

The estimation sample contains just over 5400 observations, which can be divided into two cohorts according to the age of the individual. A first younger cohort consists of individuals born from 1976 to 1988, i.e. by persons up to 35 years $(\mathrm{N}=844)$; while the older cohort is comprised of births from 1939 to 1975, with more than 35 years $(\mathrm{N}=4,599)$. The age cutoff used is justified as follows: those born from 1939 to 1975 (i.e. those with more than 35 years) were exposed to the pre-deregulated offer. Meanwhile, individuals born in 1975 (who had 35 years in 2010, the last CENAUN) were 15 years old in 1995, which was the minimum age of reference in which a young man could to apply to college. The group born this year would be the first group exposed to deregulation. Given this, it is believed that those born after cutting this year (1975) would be exposed to the post-deregulation offer.

The objective of determining both age cohorts is to distinguish the type of university provision to which the sample was exposed to professionals. For this, the 'younger cohort "was exposed to the unregulated supply, while the" older cohort "was exposed to the pre deregulation offer. In view of that, plausibly, the probability of attending a college of lower quality is higher after deregulation, each cohort correspond to different probabilities. The explanatory variables used in this estimate correspond to individual attributes (gender) and labor (work experience, graduate studies, hours worked, secondary activity indicator, career group, region of residence). 


\section{$5 \quad$ Empirical strategy}

Our goal is to explore and measure the extent to which attendance to a «lower quality» college of leads years later to the underemployment among its alumni. First, measuring university quality is required, for which we propose the construction of an index of college quality as assessed at two points in time: before and after deregulation in the higher education market. It has as input a set of observable variables that seek to measure the value of the provision of higher education services. These components are additively aggregated to obtain a college for each single score.

Second, we examine the relationship between quality and underemployment at an individually level. Evaluate it carries a methodological challenge to the extent that the decision to choose between different universities, each with different levels of quality, is correlated with individual characteristics that are not observable. As an example, consider that there is positive relationship between attending college and found lower quality underemployed. To conclude that this is a causal relationship is necessarily inaccurate, because there are young people or individuals with limited financial resources that are more vulnerable to underemployment and at the same time, because of their financial constraints are more likely to study in universities of lower quality, which typically have a lower cost. This case illustrates the difficulty in separating the effect of the quality of education of the effect of low income, as both acts on the underemployment.

In order to isolate the effect of university quality we exploit the deregulation of the market for higher education in Peru, which we evaluate in 1997 - definition of this date is explained in Section 4. Specifically, we use the supply expansion of universities post-market flexibility that occurred in $1997^{21}$ as a source of exogenous variation for professional underemployment. Thus, our identification strategy hinges on exposure to two types of university supplies: one prior to deregulation and other post-deregulation, each with a different level of aggregate quality. Formally, our overall strategy is part of a model whose basic functional form is:

$$
Y_{i j}=F\left(\gamma \mathrm{D}_{i j}, \mathrm{X}_{i j}^{\prime} \beta, \delta_{j}\right)
$$

Where $Y_{i j}$ is a dichotomous dependent variable indicating the underemployment condition corresponding to individual $i$ living in regionj. Takes the value of one $(=1)$ when the individual is underemployed and zero $(=0)$ otherwise. $D_{j i}$ is the dummy variable that indicates the quality of the college attended by the individual, specifically takes the value of one when is an institution of lower quality. $X_{i j}$ is a vector of individual characteristics including socio demographic and occupational variables ${ }^{22}$. Meanwhile, $\delta_{j}$ supports regional fixed effects related to unobservable dynamics affecting the underemployment from a regional level (eg. regional

\footnotetext{
${ }^{21}$ Universities increased documented from the creation and issuance of DL CONAFU 882 in Section 3.1.

${ }^{22}$ En todas las ecuaciones planteadas en esta sección, los coeficientes almacenados en vectores se denotan con letras en negrita. Las variables respecto a atributos individuales son descritas en la sección 4.
} 
GDP growth or professional workforce). (.) Additionally, F represents a cumulative logit distribution function (denoted $\Lambda($ ).) Specification using the same name; represents the standard normal cumulative distribution (denoted $\Phi()$.$) using the probit specification. Note that the coefficient of interest \gamma_{1}$ be estimated using the method of ordinary least squares and maximum likelihood.

Equation (1) raises two methodological challenges: (i) the $i$ individuals do not report the name of the college attended, so the classification $D_{i j}$ is not direct; and (ii) even if we had this variable, the endogenous nature results in the estimate of the coefficient of interest is biased ${ }^{23}$. To overcome both of these limitations is proposed a second stage of estimation, for which the following equation is defined:

$$
D_{i j}=\mathrm{F}\left(E_{i} \mathrm{~W}_{i}^{\prime} \alpha+\left(1-E_{i}\right) \mathrm{W}_{i}^{\prime} \delta\right)
$$

In this specification, the $D_{i j}$ variable denotes the quality of the college attended by the individual $i$, which when low takes the value of one ${ }^{24}$. The $E_{i}$ variable is a vector indicating the highest educational level attained by the father and mother of the individual, which is used as the main predictor quality of the institution you attend. $W_{i}$ is a vector of individual characteristics relevant. Finally, $\mathrm{F}($.$) represents a cumulative distribution$ function and the equation controlling for fixed effects in the region of birth of the individual.

Equation (2) is estimated for two different samples, depending on the university supply to which the individual has been exposed, that is prior to 1996 or after deregulation in 2010 (see Section 4 with details of both samples). In 1996, there was a university population who attended institutions that were not exposed to legal deregulatory scheme, i.e., were created before this process. This group of students formed the sample 1 Meanwhile, in 2010 there was a university population attending institutions created both before and after deregulation. These students make sample 2. Each group described independently determines a sample estimate, on which the equation (2) is computed.

Based on the above, we can summarize the empirical strategy of two steps. First, the probability of belonging to a university of «lower quality» $\left(D_{i j}=1\right)$ using the University Census 1996 and 2010, i.e., a pre and post deregulation context respectively estimated. These probabilities are estimated for each CENAUN. Second, the predicted probability of attending a college of lower quality $\left(\widehat{D}_{i j}\right)$ in the graduates sample is obtained from the 2004-2012 ENAHO. Then, the effect of college quality on the probability of being underemployed is estimated.

\footnotetext{
${ }^{23}$ Para una discusión del problema del «sesgo de selección» sobre parámetros asociados a la calidad universitaria, vérase por ejemplo Black \& Smith (2004), Long (2005), Hoekstra (2009), Brewer (1996), entre otros. Los autores proponen estrategias para tratar el "problema de selectividad" en la decisión de universidades de diferente calidad, el cual surge debido a la presencia de no observables como la habilidad del estudiante o el nivel socioeconómico que afectan tanto a la variable dependiente como a la variable de interés, es decir, la calidad universitaria.

${ }^{24}$ Esta variable dicotómica se construye a partir del puntaje de calidad asociado a cada universidad. La explicación de su construcción se detalla en la sección 6.
} 
In this second stage estimation, we must distinguish that deregulation of university supply involved an increase in the number of universities in general, called here effect 1. There was also an increase in lower quality universities particularly, so in the pre-deregulation existed restricted to higher education for individuals with lower skills and access regardless of the expansion of university provision, are more prone to underemployment effect - called effect 2 . The validity of these statements is analyzed in depth in section 6 . Our empirical strategy anticipates to measure these two effects of deregulation.

Considering only the first effect acting on the likelihood of attendance, we predict $\widehat{D}_{i j}$ with the coefficients associated with the university population pre-deregulation model; and $\widehat{D}_{i j}{ }^{\prime}$ with coefficient calculation obtained from the post-deregulation university population calculated based on the CENAUN from 1996 and 2010, respectively. This is done so that we can evaluate the effects of university quality lower given two «states of progress» in the post-deregulation offer. We will call this exercise «simulation» that reproduces the following scenarios.

First scenario.- We use the coefficients associated with the pre-deregulation context ( $\widehat{D}_{i j}$ of 1996). From them, all individuals in the sample are predicted probability of attending a college of lower quality, such that were exposed to pre-deregulation or university offer before CONAFU context. It is intended that the resulting probabilities under this scenario to measure the initial effect had any university quality on underemployment, as a baseline. As a result, we predict $D_{i j}$.

Second scenario.- We divided the sample into two cohorts of graduates by year of birth, to identify what kind of university offer were exposed. We use the coefficients associated with the pre-deregulation context $\left(\widehat{D}_{i j}\right.$ from 1996) to predict the likelihood of the «older cohort», in view that their estimated date of college entrance plausibly exposed them to such offer. For this stage, the coefficients of the post-deregulatory context $\left(\widehat{D}_{i j}{ }^{\prime}\right.$ from 2010) for predictions associated with «younger cohort» are used because its potential college entrance date exposed this group to the deregulated supply. As a result, it is predicted to individuals in each cohort a probability to attend a college of «lower quality», so that all young people up to 35 years were exposed to the post-deregulation and all graduates over 35 were exposed to pre-deregulation. In summary, this scenario emulates a transition period where two age sections, each with a different probability of going to a college of lower quality according to a joint exposure to two types of university offer coexist. As a result we have $D_{i j}^{\prime \prime}$.

Third scenario.- We use the coefficients associated with the post-deregulation $\left(\widehat{D}_{i j}{ }^{\prime}\right.$ from 2010$)$ context. With them we predict, for all individuals in the sample, the probability of attending college lower quality that were exposed to the university offer post-deregulation. With this scenario we seek to measure the effect of university quality on lower underemployment realizing that all graduates are or have been exposed to an unregulated supply. Thus, we reproduced scenario foreseeable future. The result is contained in $D_{i j}^{\prime}$. 
In both cases is used the same sample of professional graduates and we vary the coefficients employed to make predictions of attending a college of lower quality. With this exercise, we seek that the effect of an increased supply of lower quality universities will have effects only through the predicted probabilities. Then we proceed to dichotomize the resulting predicted variables using thresholds that replicate the average probability of attending universities lower quality according to University Census —en University section 6.2. expands on procedure. As a result, the three scenarios described in the dichotomous variable $\left(\overline{D_{l \jmath}}\right)$ represents the value of one $(=1)$ attending a lower quality university by an individual $i$ living in region $j$ is obtained. Finally, from these dichotomous variables, it is proposed to estimate equation (1). Here, the $\gamma$ parameter gives an estimated reduced form effect of attending a college of lower quality on the condition of underemployed, realizing that only the probability of attending these institutions has changed from market deregulation higher education.

Now consider that these simulation exercises must capture both the first and the second effect of deregulation. For this, the predictions of $D_{i j}^{\prime}$ and $D_{i j}^{\prime \prime}$ are made on a restricted sample of university graduates in order to replicate the diminished access to higher education that applicants with lower skills faced before deregulation. Specifically, we assume that the increase in coverage leads to higher education than those exposed to an unregulated supply are more likely to attend college. Thus, we believe that all graduates of the «younger cohort» or those that are likely associated with the post-deregulation context $\left(D_{i j}\right)$ actually attend college and are fully included in the estimation sample. On the contrary, we assume that individuals are likely to attend college shoddy linked to the pre-deregulation $\left(D_{i j}^{\prime}\right)$ or those of the «older cohort» do not assist in all cases to college because in this scenario the coverage level of higher education to applicants with lower skills were poorer. To replicate this fact, individuals with higher values of $D_{i j}^{\prime}$ (i.e., more likely to go to a university lower quality) are excluded as a way to replicate the access probability found in CENAUN. With these modifications, equation (1) is estimated again.

\section{Results}

\subsection{Measurements and evidence on college quality}

The causal line evaluated in this research consists of the following elements: (1) the expansion of university provision following a deregulatory process, (2) the overall change in quality in the higher education market, and (3) the exposure to deregulated university supply and its effects on underemployment. The first aspect is discussed in Section 3, therefore, we now present the results of analysis regarding university quality. We tested the hypothesis that proposes that the overall quality offered on the market after the deregulation is lower than its pre-deregulation levels. For this, information is available on university quality as assessed at two points in 
time: 1996 and 2010, which characterized the period before and after deregulation, respectively (as argued in Section 4). The result is the University Quality Index (ICU) shown in Table V.

The first columns correspond to 1996 and present descriptive statistics for the components of the ICU for universities created before deregulation, which amount to 57 . In the following columns we present information of 100 universities from quality measurements of 2010, grouped according to their date of creation, whether they are pre or post deregulation. From this we can conclude that universities created before deregulation have on average perform better than those created later, in four of all five components and evaluated in terms of the score for ICU — have higher scores and are statistically significant. This result suggests that universities created after deregulation contributes most to weaken the quality of higher education services, which validates the hypothesis expressed above. Finally, note in the last column the difference in average overall quality score in 1996 and 2010, calculated on the total universities each year. Comparing the performance in both years, we noticed that the quality evolution was unfavorable in absolute terms (which is expressed in the drop in average score ICU) and in the individual components related to availability of faculty, perception of educational services and research activities.

From the calculated index we developed a university ranking that classifies institutions into higher and lower quality colleges, which allows us to characterize the dynamics of exogenous expansion of university provision discussed in previous sections. Table VI shows the distribution of universities according to their quality and at two points in time. In the group of 57 universities registered CENAUN 1996, we identified that universities classified of «higher quality» accounted for 33\%. It added that there is a greater number of public universities classified «lower quality» (21) versus those of «higher quality» (8), whereas among private universities dominate those of «lower quality» (17) representing $60 \%$. This finding contraindicated to some extent the introduction of institutional measures such as LPIE, which ideally sought the entry of private institutions with better standards. These actions may stem from an optimistic assumption: the educational services that provide any private initiative would be «higher quality». However, evidence suggests that there is a profile of some inherent quality educational management.

This idea is reinforced by looking at the classification of universities in the 2010 Here we see three groups of institutions: in the first group of columns are those created until $1995\left(\mathrm{~N}_{1}=55\right)$; in the next set of columns universities created until $2010\left(\mathrm{~N}_{2}=100\right)$ are located; and finally to the universities 'incoming' or created only after deregulation $\left(\mathrm{N}_{3}=45\right)$. In the sample of universities identified the 2010 University Census, there are 55 universities created until 1995 Based on its creation date, we propose this group is a set of universities comparable to those reported in the first two columns of Table VI. So, we have a group of institutions whose qualities can be observed at two points in time. Among universities created until 1995, 67\% are classified as 
Table V. University Quality Indicators as measurement date pre or post deregulation

\begin{tabular}{|c|c|c|c|c|c|c|c|c|c|c|c|}
\hline \multirow{3}{*}{$\begin{array}{l}\text { Date indicator measurement } \\
\text { Universities by creation date } \\
\text { regarding market deregulation }\end{array}$} & \multicolumn{5}{|c|}{ University Census 1996} & \multicolumn{5}{|c|}{ University Census 2010} & \multirow{3}{*}{$\begin{array}{l}2010 / \\
1996 \\
\text { s.e. }^{4}\end{array}$} \\
\hline & \multirow{2}{*}{ Before } & \multirow{2}{*}{ After } & \multirow{2}{*}{ s.e. ${ }^{4}$} & \multicolumn{2}{|c|}{ Total } & \multirow{2}{*}{ Before } & \multirow{2}{*}{ After } & \multirow{2}{*}{ s.e. ${ }^{4}$} & \multicolumn{2}{|c|}{ Total } & \\
\hline & & & & Mean & s.d. & & & & Mean & s.d. & \\
\hline \multicolumn{12}{|l|}{ Components of indicator } \\
\hline $\begin{array}{l}\text { Ratio of teachers per one hundred (100) } \\
\text { undergraduate students }{ }^{(1)}\end{array}$ & 14.0 & 11.0 & 0.02 & 13.6 & 4.7 & 2.7 & 1.9 & $1.3^{* *}$ & 2.32 & 2.2 & $0.7^{* *}$ \\
\hline $\begin{array}{l}\% \text { Of students scoring good or excellent level of } \\
\text { university education }{ }^{(2)}\end{array}$ & 24.6 & 16.7 & 6.3 & 23.8 & 8.0 & 12.0 & 10.0 & 3.5 & 11.1 & 8.1 & $3.0^{* *}$ \\
\hline $\begin{array}{l}\% \text { Of teachers with research disseminated in } \\
\text { books for two years prior to survey }\end{array}$ & 5.5 & 0.1 & 2.0 & 4.9 & 15.5 & 5.0 & 0.1 & $0.4^{*}$ & 2.8 & 11.9 & $0.7^{* * *}$ \\
\hline $\begin{array}{l}\% \text { Of teachers who made presentations at } \\
\text { scientific meetings and / or academics }{ }^{(3)}\end{array}$ & 61.1 & 71.5 & $4.2^{*}$ & 62.2 & 18.4 & 57.4 & 51.8 & 1.6 & 54.9 & 16.8 & $1.3^{* * *}$ \\
\hline $\begin{array}{l}\text { Rating papers published in academic journals } \\
\text { indexed by Scopus }{ }^{(4)}\end{array}$ & 7.4 & 8.5 & $2.3^{* *}$ & 7.5 & 3.0 & 7.8 & 10.7 & $2.1^{* *}$ & 9.1 & 6.2 & 2.4 \\
\hline $\begin{array}{l}\text { Ratio of papers published in academic journals } \\
\text { per } 100 \text { teachers }\end{array}$ & 6.0 & 0.2 & $2.9^{*}$ & 5.4 & 19.5 & 3.5 & 0.3 & $1.4^{* *}$ & 2.1 & 7.9 & 2.7 \\
\hline University Quality Indicator (average) & 118.5 & 108.0 & 10.2 & 117 & 48 & 88.4 & 74.8 & $6.7^{* *}$ & 82 & 36 & $7.3^{* * *}$ \\
\hline Number of universities (N) & 51 & 6 & . & 57 & & 55 & 45 & . & 10 & & . \\
\hline
\end{tabular}

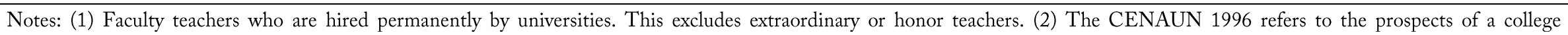

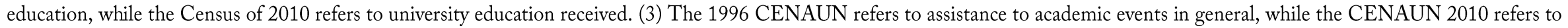

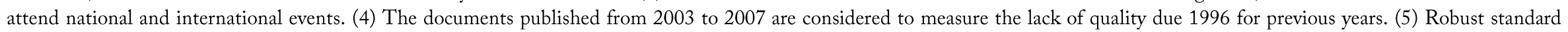

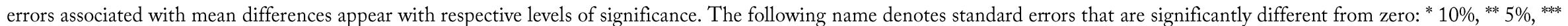
1\%. Standard errors for all variables are available for the estimation sample. Source: National Census 1996 University, 2010. 
Tabla VI. Distribution of universities, according to quality and type of university

\begin{tabular}{|c|c|c|c|c|c|c|c|c|c|c|c|c|c|c|c|c|}
\hline \multirow{4}{*}{$\begin{array}{l}\text { Universities by } \\
\text { creation date } \\
\text { regarding } \\
\text { market } \\
\text { deregulation } \\
\text { Quality level }\end{array}$} & \multicolumn{4}{|c|}{ University Census 1996} & \multicolumn{12}{|c|}{ University Census 2010} \\
\hline & \multirow{3}{*}{ Private } & \multirow{3}{*}{ Public } & \multicolumn{2}{|c|}{ Total } & \multicolumn{4}{|c|}{$\begin{array}{c}\text { Created by } 1995 \\
\text { (before deregulation) }\end{array}$} & \multicolumn{4}{|c|}{ Created by 2010} & \multicolumn{4}{|c|}{$\begin{array}{c}\text { Entrees universities } \\
1995-2010\end{array}$} \\
\hline & & & \multirow{2}{*}{$\mathrm{N}$} & \multirow{2}{*}{$\%$} & \multirow{2}{*}{ Private } & \multirow{2}{*}{ Public } & \multicolumn{2}{|c|}{ Total } & \multirow{2}{*}{ Private } & \multirow{2}{*}{ Public } & \multicolumn{2}{|c|}{ Total } & \multirow{2}{*}{ Private } & \multirow{2}{*}{ Public } & \multicolumn{2}{|c|}{ Total } \\
\hline & & & & & & & $\mathrm{N}$ & $\%$ & & & $\mathrm{~N}$ & $\%$ & & & $\mathrm{~N}$ & $\%$ \\
\hline Lower & 17 & 21 & 38 & 67 & 16 & 21 & 37 & 67 & 42 & 29 & 71 & 71 & 26 & 8 & 34 & 76 \\
\hline Higher & 11 & 8 & 19 & 33 & 12 & 6 & 18 & 33 & 23 & 6 & 29 & 29 & 11 & 0 & 11 & 24 \\
\hline Total & 28 & 29 & 57 & 100 & 28 & 27 & 55 & 55 & 65 & 64 & 100 & 100 & 37 & 8 & 45 & 100 \\
\hline
\end{tabular}

Notes: The date that the process of market deregulation begins coincides with the date of issue of the Law $\mathrm{N}^{\circ} 26.439$ whereby CONAFU was created. For calculations, the prederegulation period runs until January 21, 1995, while the later period runs from January 22 to 2010 Census of II degrees. Only two universities that reported information on the 1996 Census were created before deregulation of university market. Source: National Census 1996 University, 2010 
«lower quality». The prevalence of universities with this profile is very similar to that observed in 1996, this finding suggests that the distribution of relative quality in 2010 would have remained largely unchanged in the absence of the new universities. The term relative quality does not refer to the overall performance of university services (or how it evolves together as yet seen along section), but the distribution between universities and less high quality.

Looking at the big picture of universities created until 2010, is distinguished that the distribution of the socalled relative university quality has experienced a negative transition. This occurs to the extent that universities of lesser quality continue to dominate with a participation rate of $71 \%$, which implies a deterioration compared to 1996 (pre-deregulation). Not surprisingly, the number of «lower quality» colleges that entered the market (34) is greater than the number of institutions created to «higher quality». As such, it should be noted that lower-quality private institutions account for $58 \%$ of the expansion in the supply of universities. In conclusion, the college admissions process from market deregulation has consistently led to the distribution of quality of universities to a lower limit.

As a robustness test of the proposed ICU, we prepare a more comprehensive review of college quality to characterize some of the origins and implications of attending universities with lower quality. Family background, academic characteristics, evaluation of college and working conditions: differences in the performance of universities through a set of variables associated with quality, grouped as follows were identified. With respect to these characteristics undergraduate degree and university attributes, compares how these institutions perform according to their quality profile. Table VII presents this information to the students who made up the university population in 1996. Meanwhile, Table VIII shows the characteristics of the student population for the year 2010, is distinguished in the first set of columns to universities created before deregulation of January 1995. Information regarding universities created until 2010, i.e. all the available supply, is presented in the second set of columns; while universities incoming information is presented in the third set of columns.

First we consider the pre-college entrance features of students and how they vary with respect to the quality of the institutions they attend. In this regard, we documented that undergraduate students attending public high schools have a smaller share of universities higher quality in general, both in 1996 and in 2010 According to Leon \& Sugimaru (2013) former public school students have a lower propensity to pursue a post-secondary education due to limited available resources to make educational investments. In this context, to consider all available university supply in 2010 shows that the level of support for these students to institutions both high and lower quality remains unchanged. We emphasize that our analysis for 2010 indicates that the participation of this group of youth in institutions of higher quality created before deregulation of the market (40\%) is less 
than its share of universities 'entrees' the same profile (52\%). Therefore, it would be indicated that the expansion of supply has increased access to universities higher quality for state school students. However, this progress is tarnished to the extent that greater access to higher education has been given to universities of lower quality.

Moreover, in our analysis we note that in 2010 the average number of people financially dependent college students is significantly higher among students in institutions of lower quality. This finding presents a symptom of serious financial constraints faced by college students in order to pay for higher education services. Looking at the first two set of columns in Table VIII, a consistent pattern is observed with the financial constraints of not less than $70 \%$ of students who reported partially finance their studies, educational materials, transportation costs and other expenses related to the university. Surprisingly self-funded students in institutions of higher quality are more common at about 6.8 percentage points. This feature is consistent with the rates of employability among universities higher quality, which are more likely to provide students with jobs that provide economic resources. Among students of universities higher quality household income are reported in most cases above 1500 soles a month - in universities created before and in the total supply of 2010. On the contrary, university students of lower quality institutions most frequently reported family income between 1000 and 1500 a month in new Peruvian universities both samples soles. The concentration ranges in distant distribution of household income, is seen as a primary cause of unequal access to higher quality universities, to the extent that the cost of these educational services is on average higher.

On the other hand, students who attend higher quality universities show greater development when it comes to academic characteristics and skills. Indicators such as the average number of hours of study per week, the percentage of students who write in Spanish or possess computer skills demonstrate better preparation by the reference group. Onsite student's withdrawn percentage of higher education is statistically significant and higher in the case of universities 'lower quality' in 1996; while in 2010, the evidence indicates that these rates are statistically equal.

Now we highlight how university quality levels make a huge difference in terms of a number of outcome variables: labor and perception — see last two panels of Tables VII and VIII. Perhaps the most important difference is manifested in terms of wages. If we consider the total university operating in 2010 , the proportion of students earning less than 1000 suns is $61 \%$ in institutions lower quality, while among universities higher quality represents $35 \%$. In other words, a higher proportion of students attending universities higher quality is distributed in the categories of highest earnings, while students of institutions of lower quality tend to focus on the lowest salary ranges. In assessing students attending universities created before deregulation and "entrees" 
universities, we note that the pattern repeats. Then, regardless of their date of creation, lower quality universities are associated with a greater propensity to obtain lower labor income.

According to descriptive that correspond to 2010, it is also recorded that college students reported in fewer cases of professional activity to have attended a university of lower quality, in the above scenario as after deregulation ( $82 \%$ in contrast to $74 \%$ ). We note that the top shows overall better results in 2010 in contrast to 1996 levels, the most frequently lead students to occupations education. Thus, the average percentage of students in universities of lower quality located in professional occupations is 74\% in 2010 compared to 30\% prevalence in 1996 also higher quality universities placement improved from $40 \%$ to $82 \%$ of their students.

Looking at the perception of students in 1996, notes that $84 \%$ of the student body qualifies as good or excellent training received in college career, while $70 \%$ of students do in 2010 . This figure gives an indication of a slight dissatisfaction with educational services; however, their interpretation requires an inventory of the aspects evaluated. Moreover, we examine perceptions in 2010, noting that students in universities created before deregulation most frequently reported good or excellent for their teachers and the training evaluation.

In short, from a proposed comprehensive indicator, we have documented a significant decline in the quality of university education in two dimensions. First, we compare the absolute level of quality associated with 2010 post-deregulation, in contrast to the 1996 period that is associated with a pre deregulation scenario. We note that the quality score of the university supply available in 2010 is less than the one held in 1996. Similarly, the post-deregulation period shows a decline in relative university quality, given the increase in the participation of universities of lesser quality. Both evidences validate the assumption of our identification strategy. It is important to note that deregulation to a greater number of universities available to students choosing actually associates and has increased access to higher education of certain traditionally disadvantaged groups (e.g. alumni of public education). However, this expansion has been comprised mainly of lower quality universities, which have not only had a deteriorating effect on the quality of higher education services but have also led to the systematic admission of students to institutions of lesser quality. 
Table VII. College students' characteristics, 1996

Average percentage of students, by college

\begin{tabular}{|c|c|c|c|}
\hline & $\begin{array}{l}\text { Lower } \\
\text { quality }\end{array}$ & $\begin{array}{l}\text { Higher } \\
\text { quality }\end{array}$ & s.e. \\
\hline \multicolumn{4}{|l|}{ Individual and family characteristics } \\
\hline Graduates of public high schools & 76.4 & 43.4 & $6.7^{* * *}$ \\
\hline Number average student dependents financially ${ }^{(1)}$ & 0.782 & 0.351 & $0.071^{* * *}$ \\
\hline \multicolumn{4}{|l|}{ Academic characteristics } \\
\hline Self-funded students & 25.0 & 16.8 & $2.8^{* *}$ \\
\hline University funded students & 7.6 & 14.2 & $3.2^{* *}$ \\
\hline College drop-out during career & 23.5 & 18.4 & $2.5^{* *}$ \\
\hline Retired college during the race, due to lack of financial resources & 7.0 & 5.9 & 1.2 \\
\hline Prepared to enter university for: Individual & 41.4 & 27.1 & $3^{* * * *}$ \\
\hline Prepared to enter university for: power (tutors, academies) & 63.8 & 79.8 & $3.2^{* * *}$ \\
\hline Write, speak or read in languages other than Spanish & 33.5 & 49.2 & $5.3^{* * *}$ \\
\hline Has computer skills & 44.0 & 65.4 & 4.1 \\
\hline \multicolumn{4}{|l|}{ College rating } \\
\hline University chosen by attributes: prestige, better economic prospects & 35.7 & 67.5 & $4.9^{* * *}$ \\
\hline University chosen by student attribute: availability of career, proximity to home ${ }^{(2)}$ & 54.3 & 21.5 & $4.4^{* * *}$ \\
\hline Qualified university education: excellent or good ${ }^{(3)}$ & 66.8 & 84.3 & $3.1^{* * * *}$ \\
\hline
\end{tabular}




\section{Labor características}

Senior students got (pre) professional practices from college or faculty teacher ${ }^{(4)}$

\begin{tabular}{rrr}
22.1 & 22.1 & 4.3 \\
15.1 & 13.7 & 2.3 \\
29.6 & 40.1 & $4.3^{*}$ \\
19.2 & 20.0 & 2.6 \\
51.2 & 39.9 & $4.9^{* *}$ \\
79.4 & 88.0 & $3.0^{* *}$ \\
19.7 & 11.3 & $3.1^{*}$ \\
83.8 & 79.0 & $5.0^{*}$ \\
6.5 & 9.8 & $3.3^{* *}$ \\
5.3 & 7.3 & $2.8^{*}$ \\
\hline 37 & 18 & $\cdot$ \\
28,728 & 118,632 & $\cdot$
\end{tabular}

Senior students working in professional occupations

Students working in occupational category: professional ${ }^{(5)}$

Students working in occupational categories: technical and related

Students working in occupational category: no professional or technical

Hours worked per week: less than 42 (equivalent to $25 \%$ of total hours per week)

Hours worked per week: from $43-84$ (equivalent to $25 \%$ to $50 \%$ )

Labor income received less than 600 soles

Perceived labor income of 601-1200 soles

Perceive a higher labor income at 1200 soles

Number of universities

228,728

Notes: Robust standard errors for the difference in means are shown denoted with their respective significance levels. The following name denotes standard errors that are significantly different from zero: ${ }^{*} 10 \%, * * 5 \%, * * * 1 \%$. The reporting unit is the average percentage of students from universities that belong to each category as indicated in the columns. (1) The number of people who depend on students is expressed in average number of people. (2) The availability of career concerns the lack of supply of your chosen career by students at other universities. (3) The variable CENAUN reported for 1996 corresponds to the rating Studied college career, while the 2010 report CENAUN qualification of university education in general. (4) Senior students are those who are in the third year of university or fifth semester onwards. The percentage is calculated on the number of students in third, fourth and fifth year or equivalent semesters. (5) The percentage of students who work covers all students, ie, those from the first to the final year. The rate is calculated on all students who reported information in the census. The classification of professional occupations was performed from the first digit of the ISCO codes. Source: National University Census 1996. 
Table VIII. College student's characteristics, 2010

Average percentage of students, by college

\begin{tabular}{|c|c|c|c|c|c|c|c|c|c|}
\hline & \multicolumn{9}{|c|}{ Universities sampled by launch date } \\
\hline & \multicolumn{3}{|c|}{$\begin{array}{l}\text { Created up to } 1995 \\
\text { (before deregulation) }\end{array}$} & \multicolumn{3}{|c|}{ Created up to 2010} & \multicolumn{3}{|c|}{$\begin{array}{c}\text { Entrees universities } \\
1995-2010\end{array}$} \\
\hline & $\begin{array}{l}\text { Lower } \\
\text { quality }\end{array}$ & $\begin{array}{l}\text { Higher } \\
\text { quality }\end{array}$ & s.e. & $\begin{array}{l}\text { Lower } \\
\text { quality }\end{array}$ & $\begin{array}{l}\text { Higher } \\
\text { quality }\end{array}$ & s.e. & $\begin{array}{l}\text { Lower } \\
\text { quality }\end{array}$ & $\begin{array}{l}\text { Higher } \\
\text { quality }\end{array}$ & s.e. \\
\hline Individual and family characteristics & & & & & & & & & \\
\hline Graduates of public high schools & 76.1 & 40.1 & $6.1^{* * * *}$ & 74.7 & 44.5 & $5.0^{* * * *}$ & 73.2 & 51.8 & $7.9^{* * *}$ \\
\hline $\begin{array}{l}\text { Number average student dependents } \\
\text { financially }{ }^{(1)}\end{array}$ & 0.670 & 0.366 & $0.075^{* * * *}$ & 0.697 & 0.411 & $0.053^{* * * *}$ & 0.728 & 0.486 & $0.069^{* * *}$ \\
\hline $\begin{array}{l}\text { Students with household income under } 500 \\
\text { soles }{ }^{(2)}\end{array}$ & 28.9 & 11.2 & $3.6^{* * *}$ & 28.3 & 12.8 & $2.8^{* * * * *}$ & 27.8 & 15.5 & $4.4^{* * * *}$ \\
\hline $\begin{array}{l}\text { Students with household income from } 501 \\
\text { to } 1000 \text { soles }\end{array}$ & 32.5 & 19.9 & $2.9^{* * * *}$ & 32.5 & 22.1 & $2.3^{* * * *}$ & 32.6 & 25.8 & $3.6^{*}$ \\
\hline $\begin{array}{l}\text { Students with household income from } 1001 \\
\text { to } 1500 \text { soles }\end{array}$ & 17.7 & 16.8 & 1.7 & 17.6 & 17.2 & 1.3 & 17.4 & 17.8 & 1.9 \\
\hline $\begin{array}{l}\text { Students with household income greater } \\
\text { than } 1500 \text { soles } \\
\text { Academic characteristics }\end{array}$ & 20.9 & 52.1 & $6.6^{* * *}$ & 21.5 & 47.9 & $5.1^{* * * * *}$ & 22.2 & 41 & $7.5^{* *}$ \\
\hline Self-funded & 71.1 & 79.6 & $3.11^{* *}$ & 70.1 & 77.3 & 2.6 & 68.9 & 73.7 & 4.3 \\
\hline University funded & 7.0 & 11.2 & $1.6^{* *}$ & 8.5 & 11.4 & $1.5^{*}$ & 10.1 & 11.6 & 2.7 \\
\hline Drop-out students (during career) & 18.5 & 16.8 & 1.5 & 15.0 & 16.2 & 1.33 & 11.2 & 15.2 & $2.3^{*}$ \\
\hline $\begin{array}{l}\text { Drop-out students (during career), due lack } \\
\text { of financial resources }\end{array}$ & 6.0 & 5.5 & 0.8 & 5.3 & 5.5 & 0.7 & 4.5 & 5.5 & 1.2 \\
\hline $\begin{array}{l}\text { Preparation to enter university: by } \\
\text { individual means }\end{array}$ & 40.9 & 38.1 & 6.7 & 44.9 & 46.1 & 4.9 & 49.3 & 59.1 & $5.3^{* *}$ \\
\hline $\begin{array}{l}\text { Preparation to enter university: assisted } \\
\text { (tutors, academy) }\end{array}$ & 59.1 & 61.9 & 6.7 & 55.1 & 53.9 & 4.9 & 50.7 & 40.9 & $5.3^{* * *}$ \\
\hline Preparation time: less than 6 months & 25.5 & 22.3 & $1.8^{*}$ & 23.5 & 20.0 & $1.4^{* * *}$ & 21.3 & 16.3 & $2.3^{* *}$ \\
\hline Preparation time: 6 months to over a year & 22.7 & 27.6 & 6.4 & 18.4 & 21.4 & 4.3 & 13.7 & 11.2 & 1.2 \\
\hline Average hours of study per week & 15.0 & 17.4 & $0.8^{* * * *}$ & 13.2 & 16.0 & $2.3^{* * * *}$ & 11.2 & 13.9 & 4.4 \\
\hline $\begin{array}{l}\text { Write, speak or read in languages other } \\
\text { than Spanish }\end{array}$ & 43.1 & 64.3 & $5.2^{* * *}$ & 42.2 & 60.6 & $4.2^{* * * *}$ & 41.2 & 54.5 & $6.7^{*}$ \\
\hline Has computer skills & 84.7 & 90.3 & 1.2 & 84.4 & 90.2 & $0.9^{* * * *}$ & 84.1 & $\begin{array}{l}90.1 \\
\quad(\operatorname{col}\end{array}$ & $\begin{array}{l}1.4^{* * *} \\
\text { nues) }\end{array}$ \\
\hline
\end{tabular}




\section{University rating}

University chosen by institutions attributes: prestige, better economic perspectives

\begin{tabular}{|c|c|c|c|c|c|c|c|c|}
\hline 63.0 & 84.4 & $2.6^{* * * *}$ & 60.7 & 79.7 & $3.0^{* * * *}$ & 58.2 & 71.9 & $5.6^{* *}$ \\
\hline 32.9 & 13.5 & $2.6^{* * * *}$ & 35.3 & 17.1 & $2.8^{* *}$ & 37.9 & 23.0 & $5.4^{* * * *}$ \\
\hline 50.3 & 72.0 & $2.7^{* * *}$ & 48.5 & 70.4 & $2.4^{* * *}$ & 46.6 & 67.9 & $3.8^{* * *}$ \\
\hline 25.5 & 11.2 & $2.8^{* * * *}$ & 19.9 & 9.3 & $2.1^{* * *}$ & 13.9 & 6.3 & $2.3^{* * * *}$ \\
\hline 2.1 & 0.9 & $0.3^{* * * *}$ & 1.5 & 0.7 & $0.2^{* * * *}$ & 0.8 & 0.3 & $0.2^{* * * *}$ \\
\hline 41.1 & 58.4 & $4.7^{* * *}$ & 49.6 & 61.7 & $3.5^{* * * *}$ & 58.7 & 67.1 & $4.2^{*}$ \\
\hline 52.5 & 51.2 & 2.2 & 53.3 & 49.8 & $1.7^{* *}$ & 54.2 & 47.6 & $2.9^{* *}$ \\
\hline 25.4 & 20.6 & 3.11 & 23.9 & 20.6 & 2.9 & 22.2 & 20.5 & 5.3 \\
\hline 15.7 & 18.0 & 3.2 & 16.8 & 18.8 & 2.5 & 17.9 & 20.1 & 3.9 \\
\hline 11.0 & 5.9 & $1.4^{* * *}$ & 10.3 & 5.4 & $1.1^{* * * *}$ & 9.5 & 4.6 & $1.8^{* * * *}$ \\
\hline 19.1 & 16.7 & $1.2^{* *}$ & 19.4 & 15.9 & $1.0^{* * * *}$ & 19.8 & 14.7 & $1.7^{* * *}$ \\
\hline 69.9 & 77.4 & $2.2^{* * * *}$ & 70.3 & 78.7 & $1.9^{* * * *}$ & 70.7 & 80.7 & $3.1^{* * * *}$ \\
\hline 72.6 & 81.8 & $2.4^{* * * *}$ & 73.9 & 82.1 & $1.8^{* * * *}$ & 75.4 & 82.7 & $2.4^{* * * *}$ \\
\hline 22.6 & 15.1 & $2^{* * *}$ & 21.3 & 14.8 & $1.5^{* * * *}$ & 19.8 & 14.4 & $2.1^{* * * *}$ \\
\hline 4.8 & 3.2 & $0.5^{* * * *}$ & 4.8 & 3.1 & $0.4^{* * * *}$ & 4.8 & 2.9 & $0.7^{* * * *}$ \\
\hline 69.6 & 75.9 & $3.0^{* * *}$ & 67.7 & 72.5 & $2.626^{*}$ & 65.6 & 67 & $4.3^{*}$ \\
\hline
\end{tabular}


Hours worked per week: from 43-84

(equivalent to $25 \%$ to $50 \%$ )

27.1

50.8

21.8

$3.1^{*}$

37.6

25.4

32.6

$5.0^{*}$

29.1

25.0

49.7

37.6

Perceived labor income: from 501 to 1000

soles

Perceived labor income: from 1001 to 1500

soles

Perceived labor income: more than 1500

soles

Número de universidades

Número de estudiantes de pre-grado

(reportados en CENAUN) (8)

9.9

$3.3^{* * *}$

0.0

$2.8^{*}$

$2.8^{*}$

18

$402,698 \quad 186,965$

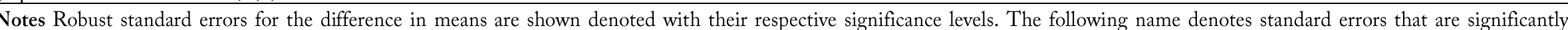

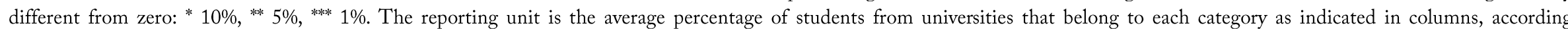

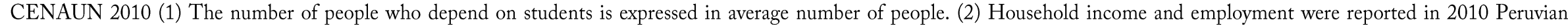

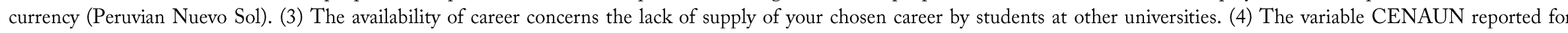

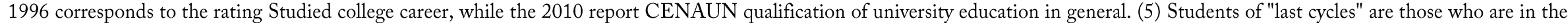

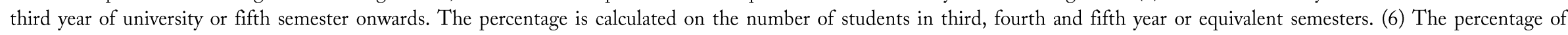

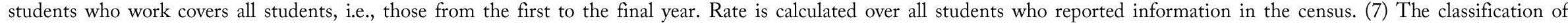

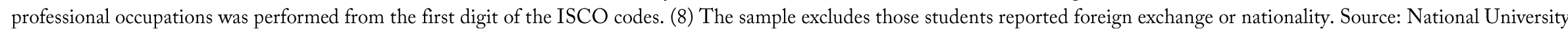
Census 2010. 
The descriptive statistics presented by the end of this section indicate that among the economic background of students, higher levels of family income or less-familiar economic burdens are negatively correlated with attending universities of lesser quality. These results highlight the importance of our empirical approach, which admits that these factors affect the decision to attend a university in one capacity or another and in turn are related to underemployment. Descriptive statistics also give evidence that the quality of inputs and processes result in unequal educational performance of students in the labor market. In particular, having attended universities 'lower quality' is positively associated with lower wage levels, increased participation in non-professional occupations and higher number of working hours - as evidence of both the 2010 and 1996 These features suggest a condition of labor market disadvantage.

\subsection{The effect of university quality in underemployment}

\section{Model of university quality: Evidence from the university population censuses}

In Table IX we report the results of estimates of discrete choice models that seek to predict attendance at lower quality universities. The dependent variables that indicate lower quality are the following two measures: to belong to the classification Lower Quality- 1 means that a student is attending a university whose ICU score is below the second third. A similar case occurs with the dependent variable Lower Quality-2, where the threshold is the third quartile. Given this, the measurement of 1 is stricter than measuring 2. Columns (1) to (4) contain the coefficients obtained under the logit specification where student characteristics as well as characteristics of their parents were included regarding educational attainment. Recall that the latter group of variables together with variables indicating the region of birth of the student, are the main predictors of university quality in the models.

The results of the first model corresponding to Low Quality 1 are presented in columns (1) and (2) corresponding to the pre and post deregulation, respectively stage. The first column shows that the coefficients associated with the educational level of father and mother are not significant, except for the higher educational level of the father. This factor is negatively associated with attending a university of lower quality under the first definition given. The indicator of birth in the Lima region also has a significant negative relationship with the dependent. For the population of students tested in 2010, corresponding to the parental education variables have positive sign and are statistically different from zero in all levels of education; as the variable indicating the region have been born in Lima. 
Table IX. Results of model estimation university quality, census-level students

\begin{tabular}{|c|c|c|c|c|c|c|c|c|}
\hline \multirow{3}{*}{$\begin{array}{l}\text { Dependent variable.- Assistance to a } \\
\text { lower quality university } \\
\text { Samples.- College students reported in: pre } \\
\text { deregulation (CENAUN 1996) or post- } \\
\text { deregulation (2010) }\end{array}$} & \multicolumn{4}{|c|}{ Probit } & \multicolumn{4}{|c|}{ Logit } \\
\hline & \multicolumn{2}{|c|}{ Lower quality-1 } & \multicolumn{2}{|c|}{ Lower quality-2 } & \multicolumn{2}{|c|}{ Lower quality-1 } & \multicolumn{2}{|c|}{ Lower quality-2 } \\
\hline & $\begin{array}{c}\text { Pre- } \\
\text { deregulation } \\
\text { (1) }\end{array}$ & $\begin{array}{c}\text { Post- } \\
\text { deregulation } \\
\text { (2) }\end{array}$ & $\begin{array}{c}\text { Pre- } \\
\text { deregulation } \\
\text { (3) }\end{array}$ & $\begin{array}{c}\text { Post- } \\
\text { deregulation } \\
\text { (4) }\end{array}$ & $\begin{array}{c}\text { Pre- } \\
\text { deregulation } \\
(5)\end{array}$ & $\begin{array}{c}\text { Post- } \\
\text { deregulation } \\
\text { (6) }\end{array}$ & $\begin{array}{c}\text { Pre- } \\
\text { deregulation } \\
(7)\end{array}$ & $\begin{array}{c}\text { Post- } \\
\text { deregulation } \\
\text { (8) }\end{array}$ \\
\hline \multirow[t]{2}{*}{ Male } & $-.249^{\text {**** }}$ & $-.0656^{* * * *}$ & $-.242^{* * * *}$ & $-.057^{* *}$ & $-.416^{\text {**** }}$ & $-.112^{\text {**** }}$ & $-.406^{\text {**** }}$ & $-.0996^{* * *}$ \\
\hline & $(.0394)$ & $(.0183)$ & $(.0454)$ & $(.0231)$ & $(.0607)$ & $(.0311)$ & $(.0735)$ & $(.0378)$ \\
\hline \multirow[t]{2}{*}{ Native language: Quechua } & $.26^{* * * *}$ & $.207^{* * * *}$ & $.198^{* * *}$ & .0506 & $.485^{* * * * *}$ & $.502^{* * * * *}$ & $.378^{* * * * *}$ & .215 \\
\hline & $(.0532)$ & $(.0527)$ & $(.0624)$ & $(.0592)$ & $(.0938)$ & $(.0985)$ & $(.113)$ & $(.138)$ \\
\hline \multirow{2}{*}{$\begin{array}{l}\text { Native language: other language, non- } \\
\text { spanish }\end{array}$} & $.11^{* *}$ & -.0654 & .0973 & -.000348 & $.195^{* *}$ & -.0678 & .178 & .035 \\
\hline & $(.0541)$ & $(.0843)$ & $(.0641)$ & $(.0422)$ & $(.0906)$ & $(.127)$ & $(.11)$ & $(.0536)$ \\
\hline \multirow[t]{2}{*}{ Father education level: secondary } & .00145 & $-.0383^{*}$ & -.0215 & $-.0645^{* * * *}$ & .00246 & $-.0754^{*}$ & -.0368 & $-.146^{* * * *}$ \\
\hline & $(.0238)$ & $(.0223)$ & $(.0247)$ & $(.0237)$ & $(.0416)$ & $(.042)$ & $(.0446)$ & $(.0334)$ \\
\hline \multirow[t]{2}{*}{ Father education level: higher } & $-.149^{*}$ & $-.252^{* * * *}$ & $-.138^{* *}$ & $-.309^{* * *}$ & $-.252^{*}$ & $-.443^{* * * *}$ & $-.233^{* *}$ & $-.581^{* * * *}$ \\
\hline & $(.0796)$ & $(.0544)$ & $(.0646)$ & $(.045)$ & $(.134)$ & $(.0908)$ & $(.112)$ & $(.051)$ \\
\hline \multirow[t]{2}{*}{ Father education level: non-reported } & .02 & $-.163^{* * *}$ & -.0173 & $-.231^{* * * *}$ & .0374 & $-.29^{* * * *}$ & -.0247 & $-.441^{* * *}$ \\
\hline & $(.0224)$ & $(.0539)$ & $(.0226)$ & $(.0297)$ & $(.0389)$ & $(.095)$ & $(.04)$ & $(.0372)$ \\
\hline \multirow[t]{2}{*}{ Mother education level: secondary } & -.0452 & $-.111^{* * * *}$ & -.0418 & $-.126^{* * * *}$ & -.0709 & $-.199^{* * * *}$ & -.0646 & $-.246^{* * * *}$ \\
\hline & $(.0455)$ & $(.0194)$ & $(.0457)$ & $(.0116)$ & $(.079)$ & $(.039)$ & $(.0814)$ & $(.0233)$ \\
\hline \multirow[t]{2}{*}{ Father education level: higher } & -.139 & $-.394^{* * * *}$ & -.137 & $-.433^{* * *}$ & -.224 & $-.666^{* * * *}$ & -.218 & $-.77^{* * * *}$ \\
\hline & $(.0994)$ & $(.051)$ & $(.0888)$ & $(.0143)$ & $(.17)$ & $(.0933)$ & $(.155)$ & $(.0514)$ \\
\hline \multirow[t]{2}{*}{ Father education level: non-reported } & $.107^{* *}$ & $-.221^{* * * *}$ & $.12^{* * *}$ & $-.294^{* * * *}$ & $.184^{* *}$ & $-.383^{* * *}$ & $.213^{* * * *}$ & $-.542^{* * * *}$ \\
\hline & $(.0512)$ & $(.0676)$ & $(.0444)$ & $(.0246)$ & $(.0898)$ & $(.121)$ & $(.0771)$ & $(.0282)$ \\
\hline Region of birth: Lima & $-.412^{* * *}$ & $-.589^{* * *}$ & $-.471^{* * *}$ & $-.718^{* * * *}$ & $-.673^{\text {**** }}$ & $-.968^{* * * *}$ & $-.785^{* * * *}$ & $-1.2^{* * *}$ \\
\hline
\end{tabular}




\begin{tabular}{|c|c|c|c|c|c|c|c|c|}
\hline \multirow{3}{*}{ Constant } & $(.0208)$ & $(.0204)$ & $(.0173)$ & $(.00794)$ & $(.0325)$ & $(.0313)$ & $(.0294)$ & $(.00642)$ \\
\hline & $.811^{* * *}$ & $1.16^{* * * *}$ & $1.04^{* * * *}$ & $1.42^{* * *}$ & $1.33^{* * * *}$ & $1.94^{* * * *}$ & $1.72^{* * *}$ & $2.45^{* * *}$ \\
\hline & $(.105)$ & $(.0488)$ & $(.0865)$ & $(.0362)$ & $(.18)$ & $(.0903)$ & $(.154)$ & $(.0316)$ \\
\hline Dummies of regions of birth & Yes & Yes & Yes & Yes & Yes & Yes & Yes & Yes \\
\hline Observations & 322,805 & 739,479 & 322,805 & 739,479 & 322,805 & 739,479 & 322,805 & 739,479 \\
\hline Log-likelihood & - 178,554 & $-371,632$ & $-168,321$ & $-302,205$ & $-178,567$ & $-371,688$ & $-168,374$ & $-302,169$ \\
\hline Iterations & 4 & 4 & 4 & 5 & 4 & 5 & 4 & 5 \\
\hline Pseudo R-square & 0.154 & 0.161 & 0.126 & 0.205 & 0.154 & 0.161 & 0.125 & 0.205 \\
\hline Cluster number & 25 & 25 & 25 & 25 & 25 & 25 & 25 & 25 \\
\hline
\end{tabular}

Notes: The model supports standard errors clustered by geographic region of birth. These are represented in parentheses. The observation unit is the college student reported in CENAUN, which has information of the name of the university you attend. The corresponding regions of birth denoted in dummy variables have as reference category region of Amazonas. The educational level of parents, refers to the maximum level reached. The reference group in these variables for both parents is Without education, with initial level or primary education, which includes parents with complete or incomplete primary level. The following scheme indicates the coefficients are significantly different from zero: ${ }^{*} 10 \% * * \%$ and $1 \%$. 
Under the definition of Lower Quality-2 are computed in columns (3) and (4) the coefficients with the same signs to the first model and in general the same patterns in terms of significance and magnitude. These results show that the associations found are stable under stringent quality measures, and in that sense are robust. Thus statistically non-significant coefficients obtained in the pre deregulation while the post stage, again seen significant estimates. We note that the magnitude of all coefficients related to parent education is higher in the model whose dependent variable measures the quality more strictly. The two groups corresponding to parent education and region of birth coefficients have the expected negative signs, which both lead to lower probabilities of attending college — para lower quality definitions 1 and 2 .

Columns (5) through (8) present the results of the models under the logit specification. Here, the coefficients found are not significant in the pre deregulation steps, under any of the definitions of quality (columns 5 and 7). As in the probit specification, the coefficients have statistical significance and the expected signs in the post deregulation (columns 6 and 8) stage. Additionally, the magnitude of coefficient is greater in the latter stage. This suggests that the relationship found is maintained under both specifications.

From the proposed models, a better fit to compute the coefficients with the dependent variable Lower Quality-1 under both specifications, is identified. To confirm that this model is used to make quality predictions, an analysis of the predicted percentage of observations that are correctly classified, where the correct classification is according to the dependent variable was performed. In Table $\mathbf{X}$ the classification corresponds to "attend to a lower quality college", while the predicted probability that results from the models of Table IX are below the average predicted probabilities for the entire university population. Note that the classification made for the period 2010 has a higher percentage of cases correctly classified in columns (2) and (4) that is, for the probit specification under the post-deregulation scenario. Another important result that guides our choice of the best model in terms of predicting the percentage of false positives and false negatives. Note that models whose dependent variable is the Lower Quality-1 presents better results in these measurements by comparing all values in columns (1) to (4) with respect to columns (5) through (8). Then, the set of coefficients associated with this model was used for the next stage of the estimates. 
Table X. Resulting classification of censored students

(based on predicted probability of attending college lower quality)

\begin{tabular}{|c|c|c|c|c|c|c|c|c|}
\hline \multirow[b]{3}{*}{$\begin{array}{l}\text { Samples. - Reported college } \\
\text { students: pre-deregulation } \\
\text { (CENAUN 1996) or post- } \\
\text { deregulation (2010) }\end{array}$} & \multicolumn{4}{|c|}{ Probit } & \multicolumn{4}{|c|}{ Logit } \\
\hline & \multicolumn{2}{|c|}{ Lower quality-1 } & \multicolumn{2}{|c|}{ Lower quality-2 } & \multicolumn{2}{|c|}{ Lower quality-1 } & \multicolumn{2}{|c|}{ Lower quality-2 } \\
\hline & $\begin{array}{l}\text { Pre- } \\
\text { deregula- } \\
\text { tion } \\
(1) \\
\end{array}$ & $\begin{array}{l}\text { Post- } \\
\text { deregula- } \\
\text { tion } \\
(2) \\
\end{array}$ & $\begin{array}{l}\text { Pre- } \\
\text { deregula- } \\
\text { tion } \\
(3) \\
\end{array}$ & $\begin{array}{l}\text { Post- } \\
\text { deregula- } \\
\text { tion } \\
(4) \\
\end{array}$ & $\begin{array}{l}\text { Pre- } \\
\text { deregulat } \\
\text { ion } \\
(5) \\
\end{array}$ & $\begin{array}{l}\text { Post- } \\
\text { deregula- } \\
\text { tion } \\
(6) \\
\end{array}$ & $\begin{array}{l}\text { Pre- } \\
\text { deregula- } \\
\text { tion } \\
(7) \\
\end{array}$ & $\begin{array}{l}\text { Post- } \\
\text { deregula- } \\
\text { tion } \\
(8) \\
\end{array}$ \\
\hline Correctly classified & 67.5 & 76.1 & 63.3 & 72.6 & 68.6 & 67.9 & 63.3 & 73.4 \\
\hline $\begin{array}{l}\text { False-positive (\%) given true } \\
\text { negative value }\end{array}$ & 21.8 & 30.4 & 22.2 & 22.6 & 24.2 & 20.3 & 22.2 & 23.6 \\
\hline $\begin{array}{l}\text { False-positive (\%) given true } \\
\text { positive value }\end{array}$ & 38.6 & 22.1 & 42.5 & 28.6 & 35.5 & 36.8 & 42.5 & 27.4 \\
\hline
\end{tabular}

Notes. Statistical apply to the university population CENAUN 1996 and 2010.

The odds of attending a lower quality university such that it was exposed to the unregulated supply are predicted with the coefficients of the selected model 2010. Similarly another set of probabilities are obtained, such that it was exposed to the unregulated supply, with the coefficients of 1996. The resulting probabilities are shown for different levels of household income in Table XI. In the first column, we see that the average probabilities associated with each income level decrease as incomes are higher in the two university populations evaluated. On the other hand, the average probability for the entire student population in 1996 amounted to 0.64, while in 2010 it is located at 0.71 . Based on this evidence, again confirming that the propensity to underemployment is higher in post-deregulation year 2010 also expanding the range of predominantly low quality context, so would most likely affect the lower income groups.

Table XI. Likely to attend universities Lower Quality-1

of the university population, by income level

\begin{tabular}{lccccr}
\hline \hline & \multicolumn{5}{c}{ Probit } \\
\cline { 2 - 6 } CENAUN 1996 & Mean & s.d. & Min. & Max. & \multicolumn{1}{c}{ N } \\
\hline Less than 600 monthly soles & 0.68 & 0.21 & 0.19 & 0.98 & 169,720 \\
From 601 to 1200 monthly soles & 0.61 & 0.20 & 0.19 & 0.98 & 97,634 \\
More than 1200 monthly soles & 0.55 & 0.17 & 0.19 & 0.97 & 45,651 \\
Total & 0.64 & 0.21 & 0.19 & 0.98 & 313,005 \\
CENAUN 2010 & & & & & \\
Less than 500 monthly soles & 0.81 & 0.16 & 0.33 & 0.99 & 151,209 \\
From 601 to 1500 monthly soles & 0.72 & 0.18 & 0.33 & 0.99 & 355,897 \\
More than 1500 monthly soles & 0.64 & 0.18 & 0.33 & 0.99 & 232,368 \\
Total & 0.71 & 0.19 & 0.33 & 0.99 & 739,474 \\
\hline Source: CENAUN 1996, 2010. & & & & &
\end{tabular}




\section{Model-employment in a sample of university graduates}

The probability of attending lower quality universities by professional college graduates is predicted from the sample chosen for ENAHO 2004-2010 - see coefficients in columns (1) model and (2) of Table IX. According to the age group of professionals, were exposed to two different offers (not deregulated and unregulated) so coefficients associated to each period are used to make predictions. The resulting probability distributions are discretized in the categories of "higher quality" and "lower quality".

Effect No.1. Increased likelihood of attending lower quality universities.- First, evaluate only the first effect of the expansion of the university offer on the condition of underemployment. All samples to evaluate this effect are described in Table XII. Significantly, by construction, the distributions sought in this table likely reproduce the average university populations present in 1996 and 2010, therefore, we present these figures to demonstrate the validity of the quality distribution that we use to estimate the effect quality on underemployment.

Recall that the expansion of university provision will be assessed so that reproduce three states forward or deregulation scenarios. Then, in a first scenario assumes that all university graduates have not been exposed to unregulated supply of universities. In this context, the distribution of professional quality levels as recorded in the first two columns of Table XII. We note that professionals attending lower quality universities represent $66 \%$ of the sample, which is close to the average value of 1996 CENAUN. The next three columns distinguish two age groups of professionals and assume that each has been exposed to a different offer. This statement is recognized to predict the likelihood of having to attend an institution of lower quality. Stresses that the youngest age group was exposed to deregulation are more involved in the universities of lower quality, in contrast to the older group. In the last column a third scenario in which all professionals have been exposed to the unregulated supply is shown.

We report in Table XIV the impact of university quality on individual underemployment measured likelihood ratios. We examine this impact only in the presence of Effect No. 1 of the expansion of university provision. Columns (1) and (2) corresponding to the stage pre-deregulation indicate that attending a college of lower quality makes $18 \%$ more likely to fall into a professional «strict underemployment», in contrast to a professional who attended an institution of higher quality. In addition, individuals under study are $12 \%$ more likely to qualify within the flexible underemployment, but the latter magnitude is not statistically significant. In columns (3) and (4) the stage of mixed exposure to unregulated supply is presented according to age groups. We note that a graduate from poor quality institutions is still more likely to be underemployed but less so with respect to the pre-deregulation. These results are counter-intuitive to the extent that was expected that exposure to deregulation increases the propensity to underemployment, implying that a group of professionals 
most likely entered universities of lower quality. However, we can argue that the measured effect depends strongly on the size of the age cuts and it is assumed that all individuals in both cuts attending college, when in fact there is evidence that the older cohort had less access to the path university. This hypothesis will be evaluated in the following sub paragraph of the document.

Finally, columns (5) and (6) show that in the scenario in which all professionals have been exposed to the unregulated supply, they are $30 \%$ more likely to be in the condition of strict underemployment, while $25 \%$ are more prone to the flexible employment. Comparing scenarios non-deregulation (columns 1,2) and full deregulation (columns 5,6) can be distinguished as follows: exposure to a range of universities of lower absolute quality and a higher proportion of institutions of this quality has caused the probability of underemployment to grow in 11 (strict definition) and 13 (flexible definition) percentage points. 
Table XII. Frequencies of quality classifications in ENAHO estimation sample

— Effect No. 1 evaluated: expansion of university supply -

(based on high or low prediction of university quality: Low Quality 1)

\begin{tabular}{|c|c|c|c|c|c|c|c|c|c|c|}
\hline \multirow{3}{*}{$\begin{array}{l}\text { Predicted university } \\
\text { quality.- by exposure } \\
\text { to university supply }\end{array}$} & \multirow{2}{*}{\multicolumn{2}{|c|}{$\begin{array}{c}\text { Pre-deregulation } \\
\qquad \beta_{1996}\end{array}$}} & \multicolumn{6}{|c|}{ Post-deregulation scenario No. 1} & \multirow{2}{*}{\multicolumn{2}{|c|}{$\begin{array}{l}\text { Pre- deregulation } \\
\qquad \beta_{2010}\end{array}$}} \\
\hline & & & \multicolumn{2}{|c|}{$\begin{array}{c}\text { Older cohort } \\
\beta_{1996} \\
\end{array}$} & \multicolumn{2}{|c|}{$\begin{array}{c}\text { Younger cohort } \\
\beta_{2010} \\
\end{array}$} & \multicolumn{2}{|c|}{ Total sample } & & \\
\hline & $\mathrm{N}$ & $\%$ & $\mathrm{~N}$ & $\%$ & $\mathrm{~N}$ & $\%$ & $\mathrm{~N}$ & $\%$ & $\mathrm{~N}$ & $\%$ \\
\hline Lower & 3,587 & 66.4 & 3,002 & 65.8 & 587 & 69.5 & 3,589 & 66.4 & $3,476.0$ & 64.3 \\
\hline Higher & 1,816 & 33.6 & 1,557 & 34.2 & 257 & 30.5 & 1,814 & 33.6 & $1,927.0$ & 35.7 \\
\hline Total & 5,403 & 100.0 & 4,559 & 100.0 & 844 & 100.0 & 5,403 & 100.0 & $5,403.0$ & 100.0 \\
\hline
\end{tabular}

Table XIII.- Frequencies of quality classifications in ENAHO estimation sample

—Effect No. $1 \& 2$ evaluated: expansion of university supply and restricted access to college for lower skill individuals (based on high or low prediction of university quality: Low Quality 1)

\begin{tabular}{|c|c|c|c|c|c|c|c|c|c|c|}
\hline \multirow{3}{*}{$\begin{array}{l}\text { Predicted university } \\
\text { quality.- by exposure to } \\
\text { university supply }\end{array}$} & \multirow{2}{*}{\multicolumn{2}{|c|}{$\begin{array}{c}\text { Pre-deregulation } \\
\beta_{1996}\end{array}$}} & \multicolumn{6}{|c|}{ Post-deregulation scenario No. 2} & \multirow{2}{*}{\multicolumn{2}{|c|}{$\begin{array}{l}\text { Pre- deregulation } \\
\qquad \beta_{2010}\end{array}$}} \\
\hline & & & \multicolumn{2}{|c|}{$\begin{array}{c}\text { Older cohort } \\
\beta_{1996}\end{array}$} & \multicolumn{2}{|c|}{$\begin{array}{c}\text { Younger cohort } \\
\beta_{2010}\end{array}$} & \multicolumn{2}{|c|}{ Total sample } & & \\
\hline & $\mathrm{N}$ & $\%$ & $\mathrm{~N}$ & $\%$ & $\mathrm{~N}$ & $\%$ & $\mathrm{~N}$ & $\%$ & $\mathrm{~N}$ & $\%$ \\
\hline Lower & 3,229 & 64.0 & 2,769 & 64.0 & 587 & 69.5 & 3,356 & 64.9 & $3,476.0$ & 64.3 \\
\hline Higher & 1,816 & 36.0 & 1,557 & 36.0 & 257 & 30.5 & 1,814 & 35.1 & $1,927.0$ & 35.7 \\
\hline Total & 5,045 & 100.0 & 4,326 & 100.0 & 844 & 100.0 & 5,170 & 100.0 & $5,403.0$ & 100.0 \\
\hline
\end{tabular}


Table XIV. Results of estimating model of professional underemployment

-Effect No. 1 evaluated: expansion of university supplyDefinición empleada: «Menor calidad-1"

\begin{tabular}{|c|c|c|c|c|c|c|}
\hline \multirow{4}{*}{$\begin{array}{l}\text { Dependent variable.- Underemployment } \\
\text { Classification of predicted quality.- } \\
\text { based on the student population in } 1996 \text { or } \\
2010\end{array}$} & \multicolumn{6}{|c|}{ Logit: odds ratios } \\
\hline & \multicolumn{2}{|c|}{$\begin{array}{c}\text { Pre-deregulation } \\
1996 \\
\end{array}$} & \multicolumn{2}{|c|}{$\begin{array}{c}\text { Post-deregulation (partial) } \\
1996,2010 \\
\end{array}$} & \multicolumn{2}{|c|}{$\begin{array}{l}\text { Post-deregulation (total) } \\
2010\end{array}$} \\
\hline & $\begin{array}{c}\text { Strict } \\
\text { underemployment }\end{array}$ & $\begin{array}{c}\text { Flexible } \\
\text { underemployment }\end{array}$ & $\begin{array}{c}\text { Strict } \\
\text { underemployment } \\
\end{array}$ & $\begin{array}{c}\text { Flexible } \\
\text { underemployment }\end{array}$ & $\begin{array}{c}\text { Strict } \\
\text { underemployment } \\
\end{array}$ & $\begin{array}{c}\text { Flexible } \\
\text { underemployment }\end{array}$ \\
\hline & $(1)$ & $(2)$ & $(3)$ & $(4)$ & $(5)$ & $(6)$ \\
\hline Lower university quality-1 (d) & $\begin{array}{l}1.188^{* * * *} \\
(0.0500)\end{array}$ & $\begin{array}{r}1.121 \\
(0.0803)\end{array}$ & $\begin{array}{r}1.160^{*} \\
(0.0971)\end{array}$ & $\begin{array}{r}1.129^{* *} \\
(0.0617)\end{array}$ & $\begin{array}{r}1.302^{* * * * *} \\
(0.107)\end{array}$ & $\begin{array}{r}1.250^{\text {**** }} \\
(0.0629)\end{array}$ \\
\hline Male (d) & $\begin{array}{r}0.469^{* * *} \\
(0.100)\end{array}$ & $\begin{array}{r}0.739 \\
(0.138)\end{array}$ & $\begin{array}{l}0.464^{* * *} \\
(0.0988)\end{array}$ & $\begin{array}{r}0.734 \\
(0.138)\end{array}$ & $\begin{array}{l}0.460^{* * *} \\
(0.0944)\end{array}$ & $\begin{array}{r}0.729 * \\
(0.135)\end{array}$ \\
\hline Labor experience & $\begin{array}{l}0.941^{* * *} \\
(0.0133)\end{array}$ & $\begin{array}{l}0.935^{* * * *} \\
(0.0116)\end{array}$ & $\begin{array}{l}0.942^{* * *} \\
(0.0134)\end{array}$ & $\begin{array}{l}0.935^{* * * *} \\
(0.0117)\end{array}$ & $\begin{array}{l}0.940^{* * *} \\
(0.0133)\end{array}$ & $\begin{array}{l}0.934^{* * * *} \\
(0.0114)\end{array}$ \\
\hline Labor experience (squared) & $\begin{array}{r}1.001^{* * * *} \\
(0.000337)\end{array}$ & $\begin{array}{r}1.001^{* * * *} \\
(0.000257)\end{array}$ & $\begin{array}{r}1.001^{* * * *} \\
(0.000339)\end{array}$ & $\begin{array}{r}1.001^{* * *} \\
(0.000258)\end{array}$ & $\begin{array}{r}1.001^{* * *} \\
(0.000335)\end{array}$ & $\begin{array}{r}1.001^{* * * *} \\
(0.000249)\end{array}$ \\
\hline Male * experience & $\begin{array}{r}1.016^{* * * *} \\
(0.00438)\end{array}$ & $\begin{array}{r}1.013^{* *} \\
(0.00521)\end{array}$ & $\begin{array}{r}1.016^{* * * * *} \\
(0.00420)\end{array}$ & $\begin{array}{r}1.013^{* *} \\
(0.00517)\end{array}$ & $\begin{array}{r}1.016^{* * *} \\
(0.00410)\end{array}$ & $\begin{array}{r}1.013^{* * *} \\
(0.00516)\end{array}$ \\
\hline Graduate studies (d) & $\begin{array}{r}0.586^{* * *} \\
(0.0810)\end{array}$ & $\begin{array}{r}0.963 \\
(0.141)\end{array}$ & $\begin{array}{r}0.586^{* * *} \\
(0.0807)\end{array}$ & $\begin{array}{r}0.964 \\
(0.141)\end{array}$ & $\begin{array}{r}0.588^{* * * *} \\
(0.0813)\end{array}$ & $\begin{array}{r}0.966 \\
(0.142)\end{array}$ \\
\hline Secondary occupation (d) & $\begin{array}{l}0.606^{* *} \\
(0.147)\end{array}$ & $\begin{array}{r}1.031^{* * * *} \\
(0.00367)\end{array}$ & $\begin{array}{l}0.606^{* *} \\
(0.143)\end{array}$ & $\begin{array}{r}1.031^{* * * *} \\
(0.00368)\end{array}$ & $\begin{array}{l}0.600^{* *} \\
(0.144)\end{array}$ & $\begin{array}{r}1.031^{* * * *} \\
(0.00367)\end{array}$ \\
\hline Weekly worked hours & $\begin{array}{r}1.038^{* * * *} \\
(0.00399)\end{array}$ & $\begin{array}{r}0.995 \\
(0.00369)\end{array}$ & $\begin{array}{r}1.038^{* * * *} \\
(0.00399)\end{array}$ & $\begin{array}{r}0.995 \\
(0.00364)\end{array}$ & $\begin{array}{r}1.038^{* * * *} \\
(0.00393)\end{array}$ & $\begin{array}{r}0.996 \\
(0.00380)\end{array}$ \\
\hline $\begin{array}{l}\text { Secondary occupation * Weekly worked } \\
\text { hours } \\
\text { Constant }\end{array}$ & $\begin{array}{r}0.998 \\
(0.00413) \\
0.145^{* * * *} \\
(0.0498) \\
\end{array}$ & $\begin{array}{r}0.623^{* * *} \\
(0.0439) \\
0.406^{* *} \\
(0.160)\end{array}$ & $\begin{array}{r}0.998 \\
(0.00402) \\
0.148^{* * *} \\
(0.0516) \\
\end{array}$ & $\begin{array}{r}0.622^{* * *} \\
(0.0430) \\
0.409^{* *} \\
(0.160)\end{array}$ & $\begin{array}{r}0.999 \\
(0.00413) \\
0.152 * * * \\
(0.0518) \\
\end{array}$ & $\begin{array}{r}0.617^{* * * *} \\
(0.0421) \\
0.416^{* *} \\
(0.160) \\
\end{array}$ \\
\hline $\begin{array}{l}\text { Dummies race groups } \\
\text { Dummies of regions of residence }\end{array}$ & $\begin{array}{l}\text { Yes } \\
\text { Yes }\end{array}$ & $\begin{array}{l}\text { Yes } \\
\text { Yes }\end{array}$ & $\begin{array}{l}\text { Yes } \\
\text { Yes }\end{array}$ & $\begin{array}{l}\text { Yes } \\
\text { Yes }\end{array}$ & $\begin{array}{l}\text { Yes } \\
\text { Yes }\end{array}$ & $\begin{array}{l}\text { Yes } \\
\text { Yes }\end{array}$ \\
\hline $\begin{array}{l}\text { Observations } \\
\text { Log-likelihood }\end{array}$ & $\begin{array}{l}5,403 \\
2,623\end{array}$ & $\begin{array}{l}5,403 \\
3,222\end{array}$ & $\begin{array}{l}5,403 \\
2,623\end{array}$ & $\begin{array}{l}5,403 \\
3,222\end{array}$ & $\begin{array}{l}5,403 \\
2,620\end{array}$ & $\begin{array}{l}5,403 \\
3,219\end{array}$ \\
\hline Iterations & 4 & 4 & 4 & 4 & 4 & 4 \\
\hline Pseudo R-squared & 0.117 & 0.082 & 0.117 & 0.082 & 0.118 & 0.083 \\
\hline Clusters & 6 & 6 & 6 & 6 & 6 & 6 \\
\hline
\end{tabular}

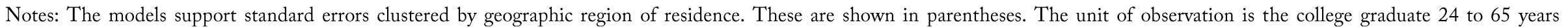

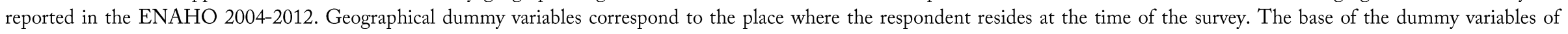

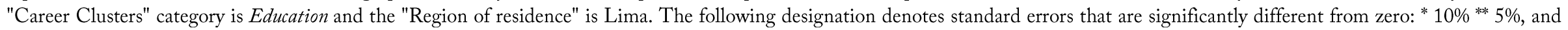
**** $1 \%$. 
Effect No.1 EO 2 Increased likelihood of attending universities 'lower quality' and restricted to pre-college deregulation.- second effect to consider access, whose probability sample of students attending an institution of restricted 'lower quality' is being associated with the pre-deregulation offer. This affects the older cohort to the extent that the empirical evidence reviewed at the beginning of the document and from this study suggests that around 2000 there was greater access to higher education. Excluding the number of observations in the sample at each stage, so was calculated such that the relative participation of professionals who attended universities 'lower quality' corresponds to the average probability recorded in 1996 CENAUN The following exclusion criteria in the sample is: eliminate observations (associated with post-deregulation probabilities) with higher probability of going to universities in low quality. It is assumed that individuals are less likely to have attended college in the pre-deregulation period are those most likely to go to college inferior. Thus, the first stage is shifted to 359 observations in the observations 94 seconds while in the latter scenario was stirred at 234 .

Table XIII shows the distribution of professionals in the categories of high and lower quality according to the levels of exposure to unregulated supply. As in the evaluation of the effect No. 1, it is possible to reproduce a distribution where the percentage of professionals included in the level of "lower quality" is similar to the value of 0.64. Meanwhile, in Table XV report the effects of university quality on the underemployment. Columns (1) and (2) shows that the odds of being employed (as defined strict) for graduates of universities of lower quality are 1.19 times higher than graduates of higher quality institutions. As in the model that evaluates the effect 1 propensity to be underemployed is lower under the second scenario compared to the stage of prederegulation. This result remains intuitive against, which suggests that the size of the subsamples groups could be influencing the effects found. Finally, a comparison of columns (1) and (5) and (6) and (2), we can conclude that the odds of falling into strict underemployment for a graduate of a college of "lower quality" has increased by approximately $10 \mathrm{pp}$. after deregulation. In turn, increased the propensity to fall flexible underemployment has grown $15 \mathrm{pp}$.

As robustness calculations that will be developed in subsequent versions of the document, in this second stage of estimation, and to evaluate the effects 1 and 2, additional controls native language Quechua and Castilian different languages were included. Preliminary results indicate that the probability of attending universities 'lower quality' increases the likelihood of underemployment 1.18 times the pre deregulation scenario, while after deregulation increases the probability 1.25 . 
Table XV. Results of estimated model of professional underemployment

—Effect No. $1 \& 2$ evaluated: expansion of university provision and restricted access to university -

Definition used: Low-quality 1

\begin{tabular}{|c|c|c|c|c|c|c|}
\hline \multirow{4}{*}{$\begin{array}{l}\text { Dependent variable. - Underemployment } \\
\text { Classification of predicted quality.- } \\
\text { based on the student population in } 1996 \text { or } \\
2010\end{array}$} & \multicolumn{6}{|c|}{ Logit: odds ratios } \\
\hline & \multicolumn{2}{|c|}{$\begin{array}{c}\text { Pre-deregulation } \\
1996 \\
\end{array}$} & \multicolumn{2}{|c|}{$\begin{array}{c}\text { Post- deregulation (partial) } \\
1996,2010\end{array}$} & \multicolumn{2}{|c|}{$\begin{array}{l}\text { Post-deregulation (total) } \\
2010 \\
\end{array}$} \\
\hline & $\begin{array}{c}\text { Strict } \\
\text { underemployment }\end{array}$ & $\begin{array}{c}\text { Flexible } \\
\text { underemployment }\end{array}$ & $\begin{array}{c}\text { Strict } \\
\text { underemployment }\end{array}$ & $\begin{array}{c}\text { Flexible } \\
\text { underemployment } \\
\end{array}$ & $\begin{array}{c}\text { Strict } \\
\text { underemployment }\end{array}$ & $\begin{array}{c}\text { Flexible } \\
\text { underemployment }\end{array}$ \\
\hline & $(1)$ & $(2)$ & (3) & $(4)$ & $(5)$ & $(6)$ \\
\hline Lower university quality-1 (d) & $\begin{array}{r}1.195^{* * * *} \\
(0.0512)\end{array}$ & $\begin{array}{r}1.108 \\
(0.0794)\end{array}$ & $\begin{array}{r}1.156^{*} \\
(0.0944)\end{array}$ & $\begin{array}{r}1.122^{*} \\
(0.0687)\end{array}$ & $\begin{array}{r}1.302^{* * *} \\
(0.107)\end{array}$ & $\begin{array}{r}1.250^{* * * *} \\
(0.0629)\end{array}$ \\
\hline Male (d) & $\begin{array}{r}0.465^{* * *} \\
(0.106)\end{array}$ & $\begin{array}{r}0.750 \\
(0.147)\end{array}$ & $\begin{array}{c}0.446^{* * *} \\
(0.0967)\end{array}$ & $\begin{array}{r}0.709^{*} \\
(0.133)\end{array}$ & $\begin{array}{l}0.460^{* * *} \\
(0.0944)\end{array}$ & $\begin{array}{r}0.729^{*} \\
(0.135)\end{array}$ \\
\hline Labor experience & $\begin{array}{l}0.940 * * * \\
(0.0143)\end{array}$ & $\begin{array}{l}0.933^{* * *} \\
(0.0133)\end{array}$ & $\begin{array}{l}0.941^{* * *} \\
(0.0150)\end{array}$ & $\begin{array}{l}0.934^{* * *} \\
(0.0124)\end{array}$ & $\begin{array}{l}0.940^{* * * *} \\
(0.0133)\end{array}$ & $\begin{array}{l}0.934^{* * *} \\
(0.0114)\end{array}$ \\
\hline Labor experience (squared) & $\begin{array}{r}1.001^{* * * *} \\
(0.000357)\end{array}$ & $\begin{array}{r}1.001^{* * *} \\
(0.000276)\end{array}$ & $\begin{array}{r}1.001^{* * *} \\
(0.000383)\end{array}$ & $\begin{array}{c}1.001^{\text {**** }} \\
(0.000283)\end{array}$ & $\begin{array}{r}1.001^{* * * *} \\
(0.000335)\end{array}$ & $\begin{array}{r}1.001^{* * *} \\
(0.000249)\end{array}$ \\
\hline Male * experience & $\begin{array}{c}1.018^{* * * *} \\
(0.00600)\end{array}$ & $\begin{array}{r}1.013^{*} \\
(0.00692)\end{array}$ & $\begin{array}{c}1.020^{\text {**** }} \\
(0.00490)\end{array}$ & $\begin{array}{c}1.016^{\text {**** }} \\
(0.00586)\end{array}$ & $\begin{array}{r}1.016^{* * *} \\
(0.00410)\end{array}$ & $\begin{array}{r}1.013^{* *} \\
(0.00516)\end{array}$ \\
\hline Graduate studies (d) & $\begin{array}{c}0.588^{* * * *} \\
(0.0873)\end{array}$ & $\begin{array}{r}0.977 \\
(0.146)\end{array}$ & $\begin{array}{c}0.596^{* * *} \\
(0.0801)\end{array}$ & $\begin{array}{r}0.970 \\
(0.139)\end{array}$ & $\begin{array}{r}0.588^{* * *} \\
(0.0813)\end{array}$ & $\begin{array}{r}0.966 \\
(0.142)\end{array}$ \\
\hline Secondary occupation (d) & $\begin{array}{l}0.539 * * \\
(0.155)\end{array}$ & $\begin{array}{r}0.743 \\
(0.165)\end{array}$ & $\begin{array}{l}0.582^{* *} \\
(0.134)\end{array}$ & $\begin{array}{r}0.801 \\
(0.168)\end{array}$ & $\begin{array}{l}0.600^{* *} \\
(0.144)\end{array}$ & $\begin{array}{r}0.777 \\
(0.160)\end{array}$ \\
\hline Weekly worked hours & $\begin{array}{r}1.037^{\text {**** }} \\
(0.00411)\end{array}$ & $\begin{array}{r}1.031^{\text {**** }} \\
(0.00389)\end{array}$ & $\begin{array}{r}1.037^{* * * *} \\
(0.00401)\end{array}$ & $\begin{array}{r}1.033^{* * * *} \\
(0.00362)\end{array}$ & $\begin{array}{r}1.038^{* * * *} \\
(0.00393)\end{array}$ & $\begin{array}{r}1.031^{\text {**** }} \\
(0.00367)\end{array}$ \\
\hline $\begin{array}{l}\text { Secondary occupation * Weekly worked } \\
\text { hours } \\
\text { Constant }\end{array}$ & $\begin{array}{r}1.037^{* * *} \\
(0.00480) \\
0.150^{* * *} \\
(0.0524) \\
\end{array}$ & $\begin{array}{r}0.996 \\
(0.00389) \\
0.412^{* *} \\
(0.174) \\
\end{array}$ & $\begin{array}{r}0.999 \\
(0.00398) \\
0.156^{* * *} \\
(0.0538) \\
\end{array}$ & $\begin{array}{r}0.994 \\
(0.00397) \\
0.319^{* * *} \\
(0.0952) \\
\end{array}$ & $\begin{array}{r}0.999 \\
(0.00413) \\
0.152^{* * * *} \\
(0.0518)\end{array}$ & $\begin{array}{r}0.996 \\
(0.00380) \\
0.416^{* *} \\
(0.160)\end{array}$ \\
\hline Dummies race groups & Yes & Yes & Yes & Yes & Yes & Yes \\
\hline Dummies of regions of residence & Yes & Yes & Yes & Yes & Yes & Yes \\
\hline Observations & 5,092 & 5,092 & 5,170 & 5,170 & 5,403 & 5,403 \\
\hline Log-likelihood & 2,493 & 3,051 & 2,526 & 3,095 & 2,620 & 3,219 \\
\hline Iterations & 4 & 4 & 4 & 4 & 4 & 4 \\
\hline Pseudo R-squared & 0.112 & 0.078 & 0.112 & 0.079 & 0.118 & 0.083 \\
\hline Clusters & 6 & 6 & 6 & 6 & 6 & 6 \\
\hline
\end{tabular}

Notes: The models support standard errors clustered by geographic region of residence. These are shown in parentheses. The unit of observation is the college graduate 24 to 65 years reported in the ENAHO 2004-2012. Geographical dummy variables correspond to the place where the respondent resides at the time of the survey. The base of the dummy variables of "Career Clusters" category is Education and the "Region of residence" is Lima. The following designation denotes standard errors that are significantly different from zero: $* 10 \% * *$, and ${ }^{* * *} 1 \%$. 
In summary, estimates of quality on two alternative measures of underemployment effects remain professional under two methodologies that reproduce the plausible effects of the expansion of university provision in the student population. Also, under both methods is identified that the lower university quality is associated with a vulnerability of underemployment on stage of university expansion and in its absence. However, we emphasize that professionals become even more prone to this condition from deteriorating university quality documented throughout this investigation.

\section{$7 \quad$ Final remarks}

This paper revolves around the challenge of university quality in the country. We exploit the exogenous process of variability in the college supply, initiated by deregulation of the higher education market, to identify the effects of university quality on individual employment. We documented a decline in the absolute quality of higher education to the extent that the overall performance of universities evaluated in CENAUN 2010 is lower than in the same 1996 census also noticeable deteriorations in quality since the relative participation of universities identified as "lower quality" increased following deregulation. In this regard, increased access to higher education after the institutional change has brought the cost of a lower quality of education. Specifically, the performance of universities created after deregulation introduced by the new legal framework, are identified as lower quality based on a number of indicators evaluated —covering teachers, educational supplies and research activities. We emphasize that universities 'lower quality' are associated with significant differences among college graduates in terms of working conditions acquired in the short term, such as occupations or earnings. Similarly, we identified that university quality has effects in the long term, to the extent that increase the propensity to fall into the professional status underemployed.

The results are consistent with the hypothesis that the lower quality of higher education received has contributed to the growing trend of underemployment since 2004. Thus, these phenomenon unfolded in the labor market have been caused, and today is reinforced, in the higher education market. The stylized facts distinguish a growth in the mass of professionals entering the labor market, which is higher than the growth in demand by the productive sector. This gap is magnified for overfull career groups. Therefore, the outlook of professional underemployment remain pessimistic if the lack of reliable information channels to clarify the needs of employers and transparent for the relevance and employability of the actual training offered by many universities persists. The ratio of university quality compared to other labor market indicators are expected to be important topics for future research. For the benefit of these studies, it is proposed as a recommendation to government authorities to include in nationally representative surveys record of the name of the institution in which college training was obtained. This information will allow the classification of educational institutions in quality scales. 


\section{References}

Alba-Ramirez, A. (1993). Mismatch in the Spanish labor market: overeducation? Journal of Human Resources, 259-278.

Allen, Jim, and Rolf Van der Valdes. (2001)"Educational mismatches versus skill mismatches: effects on wages, job satisfaction, and on-the-job search." Oxford Economic Papers 53.3: 434-452.

América Economía. "Ranking de las mejores universidades de Perú", corresponding to years 2010, 2012 y 2013. Web site: <http://www.americaeconomia.com/rankings-y-especiales $>$. Consultation date: $15^{\text {th }}$ december, 2013.

National Rectos Assembly (ANR) and National Institute of Statistics and Information (1996, 2010). University Census. Lima: INEI-ANR.

Badillo-Amador, L., García-Sánchez, A., \& Vila, L. E. (2005). Mismatches in the spanish labor market: Education vs. competence match. International Advances in Economic Research, 11(1), 93-109.

World Bank (2010). National Survey of Labor Skills, ENHAB.

Belzil, C., \& Hansen, J. (2002). Unobserved ability and the return to schooling. Econometrica, 70(5), 20752091.

Benavides, M. (2004). Educación y estructura social en el Perú. Un estudio acerca del acceso a la educación superior y la movilidad intergeneracional en una muestra de trabajadores urbanos. In: «Es Posible Mejorar la Educación peruana?: Evidencias y Posibilidades». Lima: GRADE. p. 125-146.

Benavides, M.; Etesse, M. (2012). Movilidad educativa intergeneracional, educación superior y movilidad social en el Perú: evidencias recientes a partir de encuestas a hogares. En: CUENCA, Ricardo (editor). Educación superior. Movilidad social e identidad. Lima: (IEP), pp. 51-92.

Black, D. A., \& Smith, J. A. (2004). How robust is the evidence on the effects of college quality? Evidence from matching. Journal of Econometrics, 121(1), 99-124.

Black, D. A., \& Smith, J. A. (2004). How robust is the evidence on the effects of college quality? Evidence from matching. Journal of Econometrics, 121(1), 99-124.

Black, D. A., \& Smith, J. A. (2006). Estimating the returns to college quality with multiple proxies for quality. Journal of Labor Economics, 24(3), 701-728.

Brewer, D., Eide, E., \& Ehrenberg, R. (1999). 'Does it pay to attend an elite college? Cross cohort evidence on the effects of college type on earnings. Journal of Human Resources, 34, 104-123.

Burga, C., \& Moreno, M. (2001). ¿Existe subempleo profesional en el Perú Urbano?. Lima: CIES, GRADE. 
CEDEFOP(2010). Skills supply and demand in Europe. Medium-term forecast up to 2020.

Central Bank of Peru (Banco Central de Reserva del Perú, 2000-2012) Institutional Memories. Lima: BCRP.

Clogg, C. C., \& Shockey, J. W. (1984). Mismatch between occupation and schooling: A prevalence measure, recent trends and demographic analysis. Demography, 21(2), 235-257. Nueva York: Springer.

Cohodes, S. R., \& Goodman, J. S. (2012). First degree earns: The impact of college quality on college completion rates.

Dale, S., \& Krueger, A. B. (2011). Estimating the return to college selectivity over the career using administrative earnings data (No. w17159). National Bureau of Economic Research.

de Arregui, P. M. (1993). Empleo, ingresos y ocupación de los profesionales y técnicos en el Perú. Lima: Grupo de Análisis para el Desarrollo.

Di Pietro, G., \& Urwin, P. (2006). Education and skills mismatch in the Italian graduate labour market. Applied Economics, 38(1), 79-93.

Diaz, J \& Jaramillo,M. (2008) Educación superior en el Perú: tendencias de la demanda y la oferta.

Farooq, G. M. (1986). Población y empleo en países en desarrollo. Oficina Internacional del Trabajo.

Federal Reserve Bank of New York (2013) Regional Economics Press Briefing. "Are Recent College Graduates Finding Good Jobs?” Power Point presentation from Richard Deitz, made in June 27, 2013. New York: New York FED.

Gautier, Em. (2012). Masificación y calidad de la educación superior. En: CUENCA, Ricardo (editor). Educación superior. Movilidad social e identidad. Lima: (IEP), pp. 51-92.

Groot, W., \& Maassen Van Den Brink, H. (2000). Overeducation in the labor market: a meta-analysis. Economics of education review, 19(2), 149-158.

Handel, Michael J. "Skills mismatch in the labor market." Annual Review of Sociology (2003): 135-165.

Hartog, J. (2000). Over-education and earnings: where are we, where should we go?. Economics of education review, 19(2), 131-147.

Harvey, L.; Knight, P. (1993). Transforming Higher Education. Buckingham: Society for Research in Higher Education \& Open University Press.

Hoekstra, M. (2009). The effect of attending the flagship state university on earnings: A discontinuity-based approach. The Review of Economics and Statistics, 91(4), 717-724.

Holt, R. W. (2009) Skills, Mismatch and Inequality: Labour Market Frictions and Costly Technology. Working paper. 
National Institute of Statistics and Information, INEI (2004-2012). National Household Survey, ENAHO.

National Institute of Statistics and Information, INEI (2011). II Censo Nacional Universitario, 2010. Principales resultados.

Jones-Johnson, G., \& Johnson, W. R. (1992). Subjective underemployment and psychosocial stress: The role of perceived social and supervisor support. The Journal of social psychology, 132(1), 11-21.

Keane, Michael P., and Kenneth I. Wolpin. "The career decisions of young men." Journal of political Economy 105.3 (1997): 473-522.

Keane, Michael, and Richard Rogerson. "Reconciling micro and macro labor supply elasticities." (2010).

Kirby, S. \& Holland, D. (2013). Underemployment in the UK. Londres: National Institute of Economic and Social Research.

Klein, E., \& Uthoff, A. (1988). Marcos metodológicos y conceptuales para la medición del empleo.

Korpi, Walter. "Power resources and employer-centered approaches in explanations of welfare states and varieties of capitalism: Protagonists, consenters, and antagonists." World Politics 58.2 (2006): 167-206.

León, J., \& Sugimaru, C. (2013). Entre el estudio y el trabajo: Las decisiones de los jóvenes peruanos después de concluir la educación básica regular.

Leuven, E., \& Oosterbeek, H. (2011). Overeducation and mismatch in the labor market.

Li, H., Meng, L., Shi, X., \& Wu, B. (2012). Does attending elite colleges pay in China?. Journal of Comparative Economics, 40(1), 78-88.

Liagouras, G., Protogerou, I., \& Caloghirou, Y. (2003). Exploring mismatches between higher education and the labour market in Greece. European Journal of Education, 38(4), 413-426.

Long, M. C. (2008). College quality and early adult outcomes. Economics of Education Review, 27(5), 588-602.

Manacorda, M., \& Petrongolo, B. (2006). Regional mismatch and unemployment: theory and evidence from Italy, 1977-1998. Journal of Population Economics, 19(1), 137-162.

Maynard, D. C., Joseph, T. A., \& Maynard, A. M. (2006). Underemployment, job attitudes, and turnover intentions. Journal of Organizational Behavior, 27(4), 509-536.

McCall , J. (1970): Economics of information and job search. Quarterly Journal of Economics. 84 (1): 113126.

McGuinness, S. (2003). University quality and labour market outcomes. Applied Economics, 35(18), 1943-1955

McGuinness, S. (2006). Overeducation in the labour market. Journal of economic surveys, 20(3), 387-418. 
McGuinness, Seamus. "Overeducation in the labour market." Journal of economic surveys 20.3 (2006): 387418.

Milla, J. (2012). University Quality and Labor Market: Outcomes of Canadian Youth. Ontario: University of Guelph

Nordin, Martin, Inga Persson, and Dan-Olof Rooth. "Education-occupation mismatch: Is there an income penalty?." Economics of education review 29.6 (2008): 1047-1059.

Piscoya Hermoza, L. (2006). Ranking universitario en el Perú: plan piloto.

Sahin, A., Song, J., Topa, G., \& Violante, G. L. (2011). Measuring mismatch in the US labor market. Manuscript, revised March.

Shimer, Robert. "The cyclical behavior of equilibrium unemployment and vacancies." American economic review (2005): 25-49.

Sicherman, N. (1991). " Overeducation" in the Labor Market. Journal of labor Economics, 101-122.

University of London. (2014). Frequently Asked Questions for the USA. Revisado el 22 de febrero de 2014 en la página web: <http://www.londoninternational.ac.uk/node/12648>

Vedder, R., Denhart, C. \& Robe, J. (2013). Why are recent college graduates underemployed? University enrollments and labor-market realities. Washington D.C.: Center for College Affordability and Productivity

Vedder,R. , Matgouranis, C., et al. (2010). From Wall Street to Wal-Mart: Why college graduates are not getting good jobs? Washington D.C.: Center for College Affordability and Productivity

Verdera, F. (1995). Propuestas de redefinición de la medición del subempleo y el desempleo y de nuevos indicadores sobre la situación ocupacional en Lima.

Warren, J. R. (2000). Reconsidering the relationship between student employment and academic outcomes: A new theory and better data. Youth \& Society, 33, 366-393

Wooldridge, J. M. (2013). Introductory econometrics: a modern approach. Cengage Learning.

Yamada, G.; Castro, J.F. (2013). Evolución reciente de la calidad de la educación superior en el Perú: no son buenas noticias. In: Yamada, Yamada, G.; Castro, J.F. (editors). «Calidad y acreditación de la educación superior: retos urgentes para el Perú». Lima: Universidad del Pacífico; Consejo de Evaluación, Acreditación y Certificación de la Calidad de la Educación, 2013.

Yamada, G.; Castro, J.F.; Bacigalupo, J.; Velarde, L. (2013). Mayor acceso con menor calidad en la educación superior: Algunas evidencias desde las habilidades de los estudiantes. Apuntes 72: Educación: Calidad y procesos. Lima: Universidad del Pacífico. 


\section{Appendixes}

Appendix I: Operational definition and estimation of underemployment

Table XVI. Definition of underemployment

\begin{tabular}{|c|c|}
\hline Underemployment definition & Conditions \\
\hline \multirow{2}{*}{ Naïve } & (1) Overeducation \\
\hline & (2) Working in non-professional occupations \\
\hline \multirow{3}{*}{ Strict } & (1) Overeducation \\
\hline & (2) Working in non-professional occupations \\
\hline & (3) Underpaid \\
\hline
\end{tabular}


Table XVII. Classification based on years of schooling using Clogg (1984)

\begin{tabular}{|c|c|c|}
\hline Category & Description & Formula \\
\hline Overeducated & $\begin{array}{l}\text { Individuals have an amount of years of schooling }(\mathrm{N}) \\
\text { above the mean years of schooling for the occupation } \\
\text { group }(\mu) \text { plus one standard deviation }(\sigma)\end{array}$ & $\mathrm{N} \geq \mu+\sigma$ \\
\hline $\begin{array}{c}\text { Adequately } \\
\text { educated }\end{array}$ & $\begin{array}{l}\text { Individuals have certain years of schooling }(\mathrm{N}) \text { that fall } \\
\text { in the range formed by the mean of the years of } \\
\text { schooling for the occupation group plus/minus one } \\
\text { standard deviation. }\end{array}$ & $\mu+\sigma>N>\mu-\sigma$ \\
\hline Undereducated & $\begin{array}{l}\text { Individuals have certain years of schooling }(\mathrm{N}) \text { below the } \\
\text { mean for the occupation group minus one standard } \\
\text { deviation }\end{array}$ & $\mathrm{N} \leq \mu-\sigma$ \\
\hline
\end{tabular}

Notes: Both naïve and strict underemployment rates are computed with this definition of overeducation. 
Tabla XVIII. Professional and non-professional occupations classified by occupation

$\begin{array}{cc}\text { Professional occupations } & \text { Non-professional occupations } \\ \text { (undergraduate degree required) } & \text { (undergraduate degree not required) }\end{array}$

1. Members of the executive and legislative body 3. Armed forces and police

E.g. Firms directors or associates, senior management of public.

4. Mid-level Technical and Related Workers

2. Professionals, scientific and intellectual

5. Heads and office employees

E.g. Engineers, architects, doctors, teachers, judges,

6. Skilled workers in personal services,

psychologists, administrators, economists,

protection, security and trade and market

professional actors, philosophers.

vendors

7. Farmers, skilled agricultural and fishery

workers

8. Miners, quarries, oil and related

manufacturers

9. Construction workers, and manufacturers

10. Not specified occupations, unskilled services, laborers and minor informal vendors.

Source: ENAHO 2004 to 2012. Notes: The occupations included are grouped at a one-digit SOC occupation level. 


\section{Professional labor force}

Employed

Part-time
worker

Full time worker

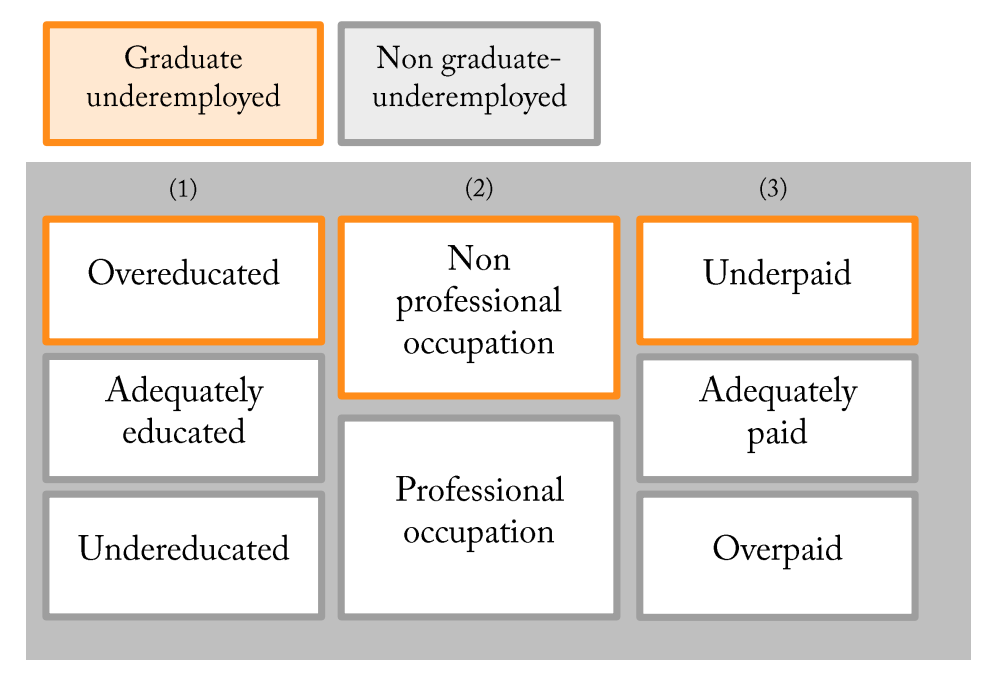

Figure VIII.- Conditions of professional employment. Conditions of being (1) overeducated, (2) working in a non-professional occupation characterize the definition of «lexible underemployment». When the condition (3) of underpaid is fulfilled, we refer to the strict definition of underemployment. 
Table XIX. Proposed classification of careers through career groups

\begin{tabular}{ll}
\hline \multicolumn{1}{c}{ Career groups } & \multicolumn{1}{c}{ Examples } \\
\hline Economy and business sciences & $\begin{array}{l}\text { Engineering management, administration and foreign trade, } \\
\text { banking and financial management services, hotel management, } \\
\text { international business. }\end{array}$ \\
Engineering and other sciences & $\begin{array}{l}\text { Agricultural engineering, construction engineering, ecology, } \\
\text { architecture, biology, chemistry, mining engineering, geology. }\end{array}$ \\
Law & $\begin{array}{l}\text { Law, corporate law, etc. } \\
\text { Communication, advertising, psychology, anthropology, } \\
\text { Humanities and social sciences }\end{array}$ \\
sociology, languages, linguistics, etc. \\
Medicine and Health Care
\end{tabular}

Source: ENAHO Survey 2004-2012. Note: ${ }^{1 /}$ These races were grouped into a single class, due to the small number of observations. 
Tabla XX. Skill profiles and associated occupations

(classified as a 2-digit ISCO codes)

\begin{tabular}{|c|c|}
\hline Codes & Type of skill \\
\hline \multicolumn{2}{|l|}{ Cognitive/Non-routine } \\
\hline 11 & Members of the executive and legislative bureau \\
\hline $12,13,14$ & Management Occupations \\
\hline 21,22 & Computer, Physics and Mathematical, architecture and Engineering Occupations \\
\hline 23 & Life, Physical, Healthcare Practitioners and Social Science Occupations \\
\hline 24 & Education, Training, and Library Occupations \\
\hline 25,26 & Legal, Business and Financial Operations Occupations \\
\hline 27 & Arts, design, entertainment and culture occupations \\
\hline 28 & Other professionals \\
\hline \multicolumn{2}{|l|}{ Manual/Non-routine } \\
\hline 31 & Members of sciences, math, physics and chemistry technic level-occupations \\
\hline 32 & Specialists in handling machinery technic level-occupations \\
\hline 33 & Technicians in navigation and aeronautics \\
\hline 34 & Computer and legal service Occupations \\
\hline 25,36 & Sales managers and business operators at a technic level \\
\hline 37,38 & Administrative service and assistants occupations \\
\hline 29 & Artists Entertainment, Sports, and Media Occupations \\
\hline \multicolumn{2}{|l|}{ Cognitive/Routine } \\
\hline 41 & Managers of minor administrative offices \\
\hline 42 & Administrative employees \\
\hline 43,44 & Service occupations (mail, transportation, etc.) \\
\hline 45 & Cashiers, receptionists and relative occupations \\
\hline 46 & Office support administrative and field operators \\
\hline 51 & Passenger service personnel \\
\hline 73 & Assistants of chemical and related processes. \\
\hline \multicolumn{2}{|l|}{ Manual/Routine } \\
\hline $52-56$ & Personal services and protective service occupations \\
\hline $57,58,91,92$ & Commerce and retail occupations \\
\hline $61,62,63,64,71,79,83,85$ & Construction and Extraction Occupations \\
\hline \multicolumn{2}{|l|}{$72,74,75,76,77,78,81,82$} \\
\hline $84,97,98$ & Production Occupations \\
\hline 87,88 & Minor machinery operators \\
\hline $93,94,95,96,98$ & Minor personal, household and city services \\
\hline
\end{tabular}

Source: ENAHO 2004-2007, Sahin et al (2013). 


\section{Appendix II: Method for estimating the wage premium (thresholds) to identify sub paid professionals}

For the estimation of wage premiums by career family, a Mincer wage regression based on individual worker's microdata for the National Household Survey of Peru was used. The Mincer equation commonly consists of a regression of the logarithm of the hourly wages on dummies for educational levels but in this case dummies were related to each career family. Additionally, potential experience variable ${ }^{25}$ and a series of sociological, demographical and educational controls were incorporated to the model. The dataset used is a pooled sample of professional individuals drawn from the ENAHO survey from 2004 to 2012 . The model has the following structure:

$$
\ln w_{i t}=\alpha+\beta_{1 t} C_{1 t}+\beta_{2 t} C_{2 t}+\beta_{3 t} C_{3 t}+\beta_{4 t} C_{4 t}+\beta_{5 t} C_{5 t}+\beta_{6 t} C_{6 t}+\beta_{8 t} C_{8 t}+\delta X_{i t}+\varepsilon_{i t}
$$

where $w$ is the wage ${ }^{26}$ for worker $i$ at time $t$, the $C$ variables are dummies that denote the career family to which the worker belongs. In that sense, the categorization of career families is introduced in the following table.

\section{Table I: Classification of career families}

\begin{tabular}{l} 
Career families \\
\hline 1. Business and Economics \\
2. Engineering and natural sciences \\
3. Law \\
4. Humanities and Social Sciences \\
5. Medicine and Health \\
6. Other careers related to health \\
7. Pedagogy \\
8. Other careers \\
Notes: The "Education" career group is not included in the \\
regression in order to avoid perfect multicollinearity between C \\
variables. Hence "Education" is the base category.
\end{tabular}

Likewise, $X$ variables represent a set of individual characteristics, which include marital status, genre, dependency, years of experience (and its square), the interaction between genre and years of experience and school education (public or private). In addition, robust standard errors are clustered by geographical region which means that observations may be independent across regions, but not necessarily within groups.

Three types of tests were accomplished to validate the model described. First, null hypothesis of linktest to asses higher order terms in the specification was rejected, hence there is no need for higher order variables. Then, the specification of the model was assessed by means of two tests. Second, the Ramsey Test for omitted variables is conducted and we accept its null hypothesis specification; thus the model is not omitting relevant

\footnotetext{
${ }^{25}$ Potential experience is measured as the following expression: $\exp =a g e-n_{-} e d u c-6$. Where age is the number of years old and $n_{-} e d u c$ is the years of education.

${ }^{26}$ Wage variable includes income earned derived from worker's principal occupation.
} 
variables. There is no data or proxy variables for ability levels in the model. Errors were are allowed to be clustered by region. Test of joint significance is applied to $C$ variables. The results give a $\mathrm{p}$-value $=0.0000$. A graphical normality test of residuals was executed. The Jacque Bera statistic for normality of residuals compelled us to so reject null that residuals are normally distributed. In the same way, joint significance is tested for $X$ variables (controls) obtaining the same result.

Table II: Hourly wage Mincer equation

\begin{tabular}{|c|c|}
\hline Dependent variable & $\begin{array}{c}\text { OLS } \\
\text { Log Hourly wage } \\
(1)\end{array}$ \\
\hline Years of education & $\begin{array}{l}0.135^{* * *} \\
(.0216)\end{array}$ \\
\hline Economic and business sciences & $\begin{array}{c}0.932^{* * * *} \\
(.0579)\end{array}$ \\
\hline Engineering and natural sciences & $\begin{array}{c}0.977^{* * * *} \\
(.0468)\end{array}$ \\
\hline Law & $\begin{array}{c}0.773^{* * * *} \\
(.0405)\end{array}$ \\
\hline Humanities and social sciences & $\begin{array}{l}0.679^{* * *} \\
(.0448)\end{array}$ \\
\hline Medicine and health & $\begin{array}{c}0.988^{* * *} \\
(.0718)\end{array}$ \\
\hline Other health careers & $\begin{array}{c}0.705^{\text {**** }} \\
(.0565)\end{array}$ \\
\hline Other careers & $\begin{array}{c}1.061^{* * *} \\
(.0945)\end{array}$ \\
\hline Marital state: married & $\begin{array}{c}0.179^{* * *} \\
(.0324)\end{array}$ \\
\hline Gender: woman & $\begin{array}{c}-1.390^{\text {**** }} \\
(.441)\end{array}$ \\
\hline Married * Woman & $\begin{array}{c}-0.105^{* *} \\
(.0392)\end{array}$ \\
\hline Years of education ${ }^{*}$ Woman & $\begin{array}{l}0.072^{* *} \\
(.0273)\end{array}$ \\
\hline Experience $*$ Worman & $\begin{array}{c}0.004^{* *} \\
(.00189)\end{array}$ \\
\hline Lima $*$ Worman & $\begin{array}{c}0.072^{* * *} \\
(.0231)\end{array}$ \\
\hline Skill profile (type of job) & $-0.104^{* * *}$ \\
\hline
\end{tabular}


Skill profile (type of job)

Residence: Lima region

Attended to private high school

Professional experience in years

O.351)

\begin{tabular}{lc}
\hline Observations & 10,122 \\
R-squared & 0.263 \\
Pseudo R-squared & 0.263 \\
Clusters & 24.000 \\
\hline
\end{tabular}

\footnotetext{
Notes: The observation unit is the college graduate. All variables are dummies, excluding education years, all interactive variables of women, estimated years of professional experience (simple and squared). The base category regarding career families corresponds to "Education". Robust standard errors adjusted by geographic region clustering appear in parentheses. The following denomination denotes coefficients that are significantly different from zero: ${ }^{*} 10 \%, * * 5 \%$, and ${ }^{* * *} 1 \%$.
}

\section{Estimation of hourly wage thresholds}

From this draw, the return rates for each career family are obtained by storing each coefficient associated with the corresponding $C$ variable. Thereby, conditional wage premium by career family is estimated. One standard deviation is subtracted from the obtained coefficients.

Since the dependent variable is in this model is a logarithm, prediction has some special features. In that sense, the first guess for predicting is to exponentiate the log of wage. Nevertheless, this application systematically underestimates the expected value of the dependent variable. This would result in an overestimation of the rate of underemployment under the strict definition. Thus, following Wooldridge (2013) and Garderen (2001), if

$$
\varepsilon \sim N\left(0, \sigma^{2}\right)
$$

then

$$
\mathrm{E}[\exp (\varepsilon)]=\exp \left(\frac{\sigma^{2}}{2}\right)
$$

Therefore, prediction should be adjusted as follows: 


$$
\left.\widehat{w}=\exp \left(\frac{\hat{\sigma}^{2}}{2}\right) \exp (\widehat{\log (w})\right)
$$

In this way, the prediction obtained is unbiased and consistent. The adjusted coefficients are used to obtain a set of predicted values of hourly wages $(\widehat{w})$. We estimate the man over this distribution to achieve the resulting hourly wage thresholds to consider an individual as underpaid are the following.

Table III: Computed hourly wage thresholds

\begin{tabular}{|c|c|c|}
\hline \multirow[t]{2}{*}{ Career group } & \multicolumn{2}{|c|}{ Threshold } \\
\hline & Mean & s.d. \\
\hline Economic and business sciences & 9.565 & 2.730 \\
\hline Engineering and natural sciences & 10.703 & 3.090 \\
\hline Law & 11.139 & 2.921 \\
\hline Humanities and social sciences & 7.658 & 2.299 \\
\hline Medicine and health & 13.846 & 3.244 \\
\hline Other health & 8.217 & 2.538 \\
\hline Education & 4.392 & 1.400 \\
\hline Other careers & 11.013 & 3.259 \\
\hline No reported career & 4.029 & 1.323 \\
\hline
\end{tabular}


Appendix III: Professional underemployment trends

Table XXI.- Professional EAP, part and full time

(university graduates, from 24 to 65 years)

\begin{tabular}{|c|c|c|c|c|c|c|}
\hline & \multicolumn{3}{|c|}{$\mathrm{N}$} & \multicolumn{3}{|c|}{$\%$} \\
\hline & Occupied & $\begin{array}{c}\text { Non } \\
\text { occupied }\end{array}$ & Total & Occupied & $\begin{array}{c}\text { Non } \\
\text { occupied }\end{array}$ & Total \\
\hline 2001 & 775,655 & 73,229 & 848,884 & 91.4 & 8.6 & 100 \\
\hline 2002 & 892,345 & 91,040 & 983,384 & 90.7 & 9.3 & 100 \\
\hline 2003 & 905,966 & 78,722 & 984,689 & 92.0 & 8.0 & 100 \\
\hline 2004 & 671,803 & 68,597 & 740,401 & 90.7 & 9.3 & 100 \\
\hline 2005 & 628,736 & 83,205 & 711,940 & 88.3 & 11.7 & 100 \\
\hline 2006 & 805,753 & 70,276 & 876,029 & 92.0 & 8.0 & 100 \\
\hline 2007 & 969,061 & 85,437 & $1,054,499$ & 91.9 & 8.1 & 100 \\
\hline 2008 & 981,972 & 75,966 & $1,057,938$ & 92.8 & 7.2 & 100 \\
\hline 2009 & $1,044,845$ & 73,179 & $1,118,024$ & 93.5 & 6.5 & 100 \\
\hline 2010 & $1,000,485$ & 74,745 & $1,075,230$ & 93.0 & 7.0 & 100 \\
\hline 2011 & $1,067,745$ & 58,002 & $1,125,747$ & 94.8 & 5.2 & 100 \\
\hline 2012 & $1,228,338$ & 64,910 & $1,293,248$ & 95.0 & 5.0 & 100 \\
\hline
\end{tabular}

Residents living in rural areas or not ordinary residents interviewed households are excluded from the sample. (2) The strict underemployment considered over-education in amateur and professional sub paid occupations; while the flexible underemployment considered as the first unique conditions. 